OPEN ACCESS

Edited by:

Lucia Gardossi,

University of Trieste, Italy

Reviewed by:

Evangelia Chronopoulou,

Agricultural University of

Athens, Greece

Madhumita Roy,

Bose Institute, India

${ }^{*}$ Correspondence:

Mohamed Neifar

mohamed.naifar@gmail.com

Specialty section:

This article was submitted to

Industrial Biotechnology,

a section of the journal

Frontiers in Bioengineering and

Biotechnology

Received: 06 January 2020 Accepted: 01 May 2020

Published: 03 July 2020

Citation:

Ouertani R, Ouertani A, Mahjoubi M,

Bousselmi Y, Najjari A, Cherif $H$, Chamkhi A, Mosbah A, Khdhira H,

Sghaier H, Chouchane H, Cherif A and Neifar M (2020) New Plant Growth-Promoting,

Chromium-Detoxifying

Microbacterium Species Isolated

From a Tannery Wastewater:

Performance and Genomic Insights.

Front. Bioeng. Biotechnol. 8:521.

doi: 10.3389/fbioe.2020.00521

\section{New Plant Growth-Promoting, Chromium-Detoxifying Microbacterium Species Isolated From a Tannery Wastewater: Performance and Genomic Insights}

\author{
Rania Ouertani ${ }^{1,2}$, Awatef Ouertani ${ }^{1}$, Mouna Mahjoubi ${ }^{1}$, Yosra Bousselmi ${ }^{1}$, Afef Najjari ${ }^{2}$, \\ Hanene Cherif ${ }^{1}$, Asma Chamkhi ${ }^{1}$, Amor Mosbah ${ }^{1}$, Hechmi Khdhira ${ }^{3}$, Haitham Sghaier ${ }^{1,4}$, \\ Habib Chouchane ${ }^{1}$, Ameur Cherif ${ }^{1}$ and Mohamed Neifar ${ }^{1 *}$ \\ ${ }^{1}$ Univ. Manouba, ISBST, BVBGR-LR11ES31, Biotechpole Sidi Thabet, Sidi Thabet, Tunisia, ${ }^{2}$ Laboratory of Microorganisms \\ and Active Biomolecules, MBA-LRO3ESO3, Faculty of Sciences of Tunis, University of Tunis El Manar, Tunis, Tunisia, \\ ${ }^{3}$ Management Environment Responsible in Tanneries Mégisseries du Maghreb, TMM, Grombalia, Tunisia, ${ }^{4}$ Laboratory \\ "Energy and Matter for Development of Nuclear Sciences" (LR16CNSTNO2), National Center for Nuclear Sciences and \\ Technology (CNSTN), Sidi Thabet Technopark, Sidi Thabet, Tunisia
}

Hexavalent chromium [Cr(VI)], widely generated by tannery activities, is considered among the most toxic substances and causes a serious damage for the environment and for human health. Interestingly, some microorganisms have a potential of bioremediation of chromium-contaminated wastewaters and soils through the reduction of $\mathrm{Cr}(\mathrm{VI})$ (soluble and harmful form) into Cr(III) (stable and non-toxic form). Here, we present the full genome sequence of a novel heavy-metal-resistant, plant growth-promoting bacterium (PGPB), Microbacterium metallidurans TL13, which was isolated from a Tunisian leather industry. The strain TL13 was resistant to many heavy metals, such as chromium, copper, nickel, cobalt, and arsenic. The 50\% TL13 growth inhibitory concentration $\left(\mathrm{IC}_{50}\right)$ values of $\mathrm{HgCl}_{2}$, $\mathrm{CoCl}_{2}, \mathrm{~K}_{2} \mathrm{Cr}_{2} \mathrm{O}_{7}, \mathrm{CuSO}_{4}, \mathrm{NiCl}_{2}, \mathrm{FeSO}_{4}$, and $\mathrm{Na}_{2} \mathrm{HAsO}_{4}$ are 368, 445, 676, 1,590, 1,680, 4,403, and 7,007 $\mathrm{mg} / \mathrm{L}$, respectively, with the following toxicity order: $\mathrm{HgCl}_{2}>\mathrm{CoCl}_{2}$ $>\mathrm{K}_{2} \mathrm{Cr}_{2} \mathrm{O}_{7}>\mathrm{CuSO}_{4}>\mathrm{NiCl}_{2}>\mathrm{FeSO}_{4}>\mathrm{Na}_{2} \mathrm{HAsO}_{4}$. This new strain was also able to promote the growth of the hybrid tomato (Elika F1) under chromium metal stress. Its whole genome sequence length was estimated to be 3,587,460 bp (3,393 coding sequences) with a $\mathrm{G}+\mathrm{C}$ content of $70.7 \%$. Functional annotation of the genome of TL13 revealed the presence of open reading frames (ORFs) involved in adaptation to metal stress, such as the chromate transport protein, cobalt-zinc-cadmium resistance protein, copper resistance protein, copper responsive transcriptional regulator, multidrug resistance transporters, arsenical resistance operon repressor, arsenate reductase, arsenic resistance protein, mercuric resistance operon regulatory protein, mercuric ion reductase, and organomercurial lyase. Moreover, genes for the production of glutathione peroxidase, catalase, superoxide dismutase, and thioredoxin reductase, which confer a higher tolerance to oxidative/metal stresses, were identified in TL13 genome. In addition, genes for heat shock tolerance, cold shock tolerance, glycine-betaine production, mineral phosphate solubilization, ammonia assimilation, siderophores, 
exopolysaccharides, polyketides, and lytic enzymes (cellulase, chitinase, and proteases) production that enable bacteria to survive biotic/abiotic stress and to promote plant growth and health were also revealed. Based on genome analysis and experimental approaches, strain TL13 appears to have evolved from various metabolic strategies and could play a role in ensuring sustainable environmental and agricultural systems.

Keywords: actinobacterium, bioremediation, genome annotation, heavy metals, plant growth promotion, tannery wastewater

\section{INTRODUCTION}

The leather industry plays an important role in the world's economy. This industry uses a raw material that is originally a livestock coproduct. Leather making consists of converting putrescible hides and skins into a more resistant commercial leather (Fang et al., 2017). In fact, this process comprises three main operations: (i) beamhouse operation, which consists of several steps aimed to eliminate all components other than collagen; (ii) tanning operation, which provides resistant leather using chromium; and (iii) finishing operation, which consists of giving the treated leather its last aspect ready for commercialization. During the process of leather making, several baths containing chemicals harmful to the environment are used in order to treat hides and skins. Indeed, spilled water has a significant pollutant load (Thanikaivelan et al., 2004). Around $30 \mathrm{~m}^{3}$ of effluents is generated for every ton of hides and skins, which have significant impacts on environments and human health due to the presence of heavy metals especially chromium (Suthanthararajan et al., 2004). The toxic form of this metal $[\mathrm{Cr}(\mathrm{VI})]$ seems to be the cause of the contamination of aquatic and terrestrial ecosystems and also the cause of several diseases such as cancer, particularly lung cancer (Pradhan et al., 2016).

Despite its toxicity (Balmer, 2018), hexavalent chromium $[\mathrm{Cr}(\mathrm{VI})]$ could be removed with an ecofriendly method using microorganisms, a process called bioremediation. Many studies have proven the effectiveness of bacteria and fungi for the reduction of $\mathrm{Cr}(\mathrm{VI})$ in chromium-contaminated effluents and soils and the ability to transform it into $\mathrm{Cr}$ (III) (Chai et al., 2019). Several bacterial strains are known as potential chromium reducers, such as Enterobacter sp. HU38, Pantoea stewartii ASI11 (Ashraf et al., 2018), Cellulosi microbium sp. (Bharagava and Mishra, 2018), Brucella sp. K12 (Maqbool et al., 2015), Escherichia coli (Learman et al., 2011), Amphibacillus sp. KSUCr3 (Ibrahim et al., 2012), Pseudomonas aeruginosa CCTCC AB93066 (Kang et al., 2014), and Bacillus firmus KUCr1 (Sau et al., 2010). Microbacterium strains, being able to tolerate or resist various heavy metals such as chromium, arsenic, nickel, and cadmium, have been found to be suitable bacteria for bioremediation (Soni et al., 2014; Gutiérrez et al., 2015; Wu et al., 2015; Lun et al., 2016; Elahi et al., 2019; Kumar and Saini, 2019). Microbacterium species have been recently described as efficient plant growthpromoting bacterium (PGPB) although under biotic and abiotic stresses (Manzanera et al., 2015; Jana et al., 2017; Passari et al., 2019a).
In recent years, several bacterial whole genomes were sequenced in order to identify loci involved in metal resistance, particularly chromium reduction and resistance. Genomic annotations indicated that $c h r R$ and yieF are implicated in the mechanism of chromate reduction. In fact, some bacterial strains, like E. coli, use YieF reductase to reduce $\mathrm{Cr}(\mathrm{VI})$ into $\mathrm{Cr}(\mathrm{III})$. Other species, like Pseudomonas putida, are known for their chromium reduction through the ChrR reductase (RamirezDiaz et al., 2008; Learman et al., 2011; Ahemad and Kibret, 2014; Henson et al., 2015; Baldiris et al., 2018). Otherwise, $M$. laevaniformans strain OR221 was able to resist some heavy metals, but the annotation of its genome after sequencing suggested the absence of both ChrR and YieF (Brown et al., 2012). In this paper, we describe the identification of a novel heavymetal-resistant, PGPB M. metallidurans TL13, isolated from a tannery effluent. TL13 could prove to be a suitable candidate for the bioremediation of heavy-metal-contaminated soils and wastewaters and also could be used as a biofertilizer due to its traits. The complete genome sequencing and annotation of TL13 were conducted, and experimental data were collected, in order to better understand its mechanisms of chromium resistance and reduction and genes involved in stress resistance and PGP activities.

\section{MATERIALS AND METHODS}

\section{Reagents and Chemicals}

All chemicals and reagents used in this study are of pure analytical grade and available commercially.

\section{Isolation and Characterization of a Novel Heavy-Metal-Resistant Bacterium}

In this study, a heavy-metal-resistant bacterium strain TL13 was isolated from tannery (TMM) wastewater using tryptic soy agar (TSA). Water content, total organic carbon (TOC), organic content, and total heavy metal content from the sludge generated in TMM wastewater treatment plants were determined by gravimetry, calcination, colorimetry, and inductively coupled plasma atomic emission spectroscopy (ICP-OES) according to the standards ISO 12880: 2000, Rodier, NF ISO 14235: 1998 and ISO 1188: 2007, respectively (Zeng et al., 2016).

Analysis of bacterial resistance to heavy metals was carried out on TSA medium supplemented with increasing concentrations $(50-2,500 \mathrm{mg} / \mathrm{L})$ of iron sulfate $\left(\mathrm{FeSO}_{4}\right)$, copper sulfate $\left(\mathrm{CuSO}_{4}\right)$, cobalt chloride $\left(\mathrm{CoCl}_{2}\right)$, disodium arsenate $\left(\mathrm{Na}_{2} \mathrm{HAsO}_{4}\right)$, potassium dichromate $\left(\mathrm{K}_{2} \mathrm{Cr}_{2} \mathrm{O}_{7}\right)$, mercury chloride $\left(\mathrm{HgCl}_{2}\right)$, 
and nickel chloride $\left(\mathrm{NiCl}_{2}\right)$. The spot inoculation method was used to involve in triplicate $10 \mu$ l of bacterial culture suspension $\left(10^{8} \mathrm{CFU} / \mathrm{mL}\right.$ ) (Fu et al., 2016). Bacterial cultures were incubated for $24 \mathrm{~h}$ at $30^{\circ} \mathrm{C}$ to determine minimum inhibitory concentrations (MIC) (Davis, 2005). A positive control was used by inoculating bacterial suspension on agar plates without metal. The half maximal inhibitory concentration $\left(\mathrm{IC}_{50}\right)$ was determined using experiments conducted in tryptic soy broth (TSB) medium at $30^{\circ} \mathrm{C}$ with shaking at $120 \mathrm{rpm}$ (Fassy et al., 2017). Bacterial growth was measured after $24 \mathrm{~h}$ on a UV-visible (UV-Vis) spectrophotometer at $600 \mathrm{~nm}$. All experiments (solid and liquid) were performed under alkaline conditions ( $\mathrm{pH} 9$ ). Metal reduction was determined by inductively coupled plasma mass spectrometry. Bacterial cell free extracts were recovered after a $10 \mathrm{~min}$ of centrifugation at $10,000 \mathrm{rpm}$ and then filtered using $0.22 \mu \mathrm{m}$ Whatman filter paper.

\section{Plant Growth-Promoting Activities In vitro Screening of TL13 for Its Plant Growth-Promoting Activities}

The screening of TL13 strain for various in vitro plant growthpromoting activities was performed by adopting standard methods (Hassen et al., 2018). Inorganic phosphate-solubilizing activity and growth on nitrogen free medium was estimated by the method of Pikovskaya (1948) and Jensen (1942), respectively. To detect the ability of TL13 strain to produce siderophore, chrome azurol sulfonate (CAS) agar solid medium was used (Alexander and Zuberer, 1991). Cellulase activity was tested on minimal medium amended with $1 \%$ carboxymethyl cellulose (CMC) (Souii et al., 2018). The protease production was screened by skim milk agar (Ouertani et al., 2018). The ability of TL13 to produce indole-3-acetic acid (IAA) and exopolysaccharides (EPS) was assessed as indicated by Penrose and Glick (2003) and Naseem et al. (2018), respectively.

\section{In vivo Plant Growth Promotion Assays}

In vivo plant growth promotion and tomato seed germination assays were performed as described by Passari et al. (2019a) with slight modification. Elika F1 tomato seeds were surface sterilized with $1 \%$ sodium hypochlorite solution for $20 \mathrm{~min}$ and subsequently rinsed three times with sterile distilled water. Disinfected Elika F1 tomato seeds were immersed for $2 \mathrm{~h}$ in a TL13 bacterial suspension $\left(10^{8} \mathrm{CFU} / \mathrm{mL}\right)$. Seeds immersed in sterile distilled water served as a control. A sterile Whatman paper was soaked in a chromium solution at different concentrations $(0,100$, and $500 \mathrm{mg} / \mathrm{L})$ and deposited in Petri dishes. Seeds were then gently deposited on Whatman filter paper under appropriate conditions, incubated in darkness at $30^{\circ} \mathrm{C}$ for 8 days and irrigated every day with sterile distilled water. Germination percentages were calculated by dividing total germinated seeds to total number of seeds that were planted (Passari et al., 2019a,b). The experiment was repeated three times using 20 Elika F1 tomato seeds per germination condition. Different parameters, including shoot length, shoot fresh, and dry weights, were measured.

\section{Antibiotic Sensitivity Test}

The Kirby-Bauer test, known as the disk-diffusion method, was performed to determine antibiotic sensitivity of TL13 strain (Bauer et al., 1966). A pure culture of TL13 strain was diluted using saline solution and adjusted to $10^{8} \mathrm{CFU} / \mathrm{mL}$. Bacterial inoculum was then streaked on Mueller Hinton agar using a sterile swab. Antibiotics used were cefoxitin (FOX, $30 \mu \mathrm{g})$, pristinamycin (PTN, $15 \mu \mathrm{g}$ ), neomycin (NE, $30 \mu \mathrm{g}$ ), rifampicin (RD, $30 \mu \mathrm{g})$, norfloxacin (NOR, $5 \mu \mathrm{g}$ ), streptomycin (S, $10 \mu \mathrm{g})$, erythromycin (E, $15 \mu \mathrm{g}$ ), cefotaxime (CTX, 30 $\mu \mathrm{g}$ ), tetracycline (TET, $30 \mu \mathrm{g}$ ), vancomycin (VAN, $30 \mu \mathrm{g}$ ), ceftazidime (CAZ, $30 \mu \mathrm{g}$ ), spiramycin (SP, $100 \mu \mathrm{g}$ ), and oxytetracyclin (OT, $30 \mu \mathrm{g}$ ). Antibiotic impregnated disks were placed on agar plates and incubated for $72 \mathrm{~h}$ at $30^{\circ} \mathrm{C}$. Bacterial resistance or sensitivity was determined by measuring the zone of inhibition.

\section{Genome Sequencing, Assembly, and Annotation of TL13 Strain}

Genomic DNA extraction of TL13 strain was performed by sodium dodecyl sulfate-proteinase $\mathrm{K}$ treatment (Neifar et al., 2019). Purified genomic DNA was sequenced on an Illumina MiSeq platform (MRDNA, USA) yielding $2 \times 250$ bp pairedend reads. The Prinseq-lite software was used for trimming the 4,320,030 paired reads by discarding low-quality sequences with a score lower than 23 (Mahjoubi et al., 2019). Genome assembly was then performed using the SPAdes algorithm (Bankevich et al., 2012). Genome annotation was done using the Integrated Microbial Genomes/Expert Review (IMG/ER) database (Markowitz et al., 2009) and the Rapid Annotations using Subsystems Technology (RAST) server (Aziz et al., 2008). Annotated protein sequences were downloaded from the National Center for Biotechnology Information (NCBI) (Galperin et al., 2015) and the Kyoto Encyclopedia of Genes and Genomes (KEGG) (Ogata et al., 1999) databases.

\section{Phylogenetic Analysis}

The $16 \mathrm{~S}$ ribosomal DNA (rDNA) gene sequence was annotated within the genome and compared to sequences of bacterial strains from the NCBI and EzBioCloud databases (Kim et al., 2012). The phylogenetic tree was inferred by the neighborjoining method using the Molecular Evolutionary Genetics Analysis (MEGA 6) software (Kumar et al., 2016). A 95$96 \%$ average nucleotide identity (ANI) value was used as a genomic measure for prokaryotic species delineation (Richter et al., 2016) and was measured using the JSpecies Web Server (JSpeciesWS) available at http://jspecies.ribohost.com/ jspeciesws. A circular genome map was drawn used CGView software (Grant and Stothard, 2008).

\section{Structural Analysis}

The structures of enzymes involved in chromate reduction were predicted by the online structure prediction tool, Iterative Threading ASSEmbly Refinement server (I-TASSER) (Yang and Zhang, 2015; Ouertani et al., 2018). The confidence score (C score) was used to identify the best generated model, and MolProbity was applied to evaluate the refined model coordinates 
TABLE 1 | Physicochemical characteristics of a TMM raw sludge sample.

\begin{tabular}{lc}
\hline Parameters & Values \\
\hline Moisture (\%) & 68.2 \\
Organic content (g/kg-dry sludge) & 601 \\
TOC (mg/kg-dry sludge) & 353 \\
Cadmium (mg/kg-dry sludge) & $<0.6$ \\
Cobalt (mg/kg-dry sludge) & $<5.0$ \\
Copper (mg/kg-dry sludge) & 7.11 \\
Iron (mg/kg-dry sludge) & $16.4 \times 10^{3}$ \\
Lead (mg/kg-dry sludge) & 7.52 \\
Nickel (mg/kg-dry sludge) & 47.05 \\
Zinc (mg/kg-dry sludge) & 561.7 \\
Chromium (mg/kg-dry sludge) & $26.2 \times 10^{3}$ \\
Arsenic (mg/kg-dry sludge) & $<1.0$ \\
Selenium (mg/kg-dry sludge) & 4.6 \\
Antimony (mg/kg-dry sludge) & 302.7 \\
Tin (mg/kg-dry sludge) & $<1.0$ \\
Silver (mg/kg-dry sludge) & 12.86 \\
Boron (mg/kg-dry sludge) & $<1.0$ \\
Baryum (mg/kg-dry sludge) & 33.04 \\
Beryllium (mg/kg-dry sludge) & $<1.0$ \\
Molybdenum (mg/kg-dry sludge) & $<1.0$ \\
Titanium (mg/kg-dry sludge) & 17.47 \\
Mercury (mg/kg-dry sludge) & $<1.0$ \\
\hline
\end{tabular}

(Davis et al., 2007). Enzyme models were assessed using COACH software (Yang et al., 2013). A final analysis with CCP4mg molecular-graphics software was performed to validate the quality of the structures (McNicholas et al., 2011).

\section{Statistical Analysis}

Experimental results were expressed as the mean value of three independent replicates \pm the standard deviation (SD). Data were analyzed using one-way ANOVA with post-hoc Duncan's tests (SPSS 16.0 for Windows, SPSS Inc., USA). Statistical significance was determined as $p<0.05$.

\section{Nucleotide Sequence Accession Number}

The Whole Genome Shotgun project was deposited at DDBJ/ENA/GenBank under the accession SZZQ00000000. The version reported in this work is SZZQ01000000 (https:// www.ncbi.nlm.nih.gov/nuccore/SZZQ00000000).

\section{RESULTS}

\section{Characterization of a Heavy-Metal-Resistant, Plant Growth-Promoting Actinobacterium Isolated From a Tannery Wastewater}

The physicochemical composition of the sludge collected from TMM industry is shown in Table 1. The content of chromium in sludge exceeds the thresholds for agriculture, according to national and international standards (Jakov, 2005). Qualitative analyses indicated that TL13 strain has the capacity to grow in the presence of $\mathrm{K}_{2} \mathrm{Cr}_{2} \mathrm{O}_{7}$ concentrations that could exceed $1,000 \mathrm{mg} / \mathrm{L}$ (Figure 1A). The bacterial growth was followed in the presence of $\mathrm{K}_{2} \mathrm{Cr}_{2} \mathrm{O}_{7}$ with variable concentrations ranging from 50 to 2,500 mg/L on TSB medium. As shown in Figure 1B, TL13 strain tolerated more than $1,000 \mathrm{mg} / \mathrm{L}$ of $\mathrm{K}_{2} \mathrm{Cr}_{2} \mathrm{O}_{7}$. The TL13 $\mathrm{IC}_{50}$ of $\mathrm{K}_{2} \mathrm{Cr}_{2} \mathrm{O}_{7}$ is equal to $676 \mathrm{mg} / \mathrm{L}$ (Figure 1C). ICPMS analysis revealed that TL13 strain was able to reduce $71.68 \%$ of chromium [Cr(VI)] with initial concentration of $500 \mathrm{mg} / \mathrm{L}$ $\mathrm{K}_{2} \mathrm{Cr}_{2} \mathrm{O}_{7}$. Heavy metal resistance experiments indicated also that TL13 strain has the capacity to grow under high concentrations of $\mathrm{FeSO}_{4}$ and $\mathrm{Na}_{2} \mathrm{HAsO}_{4}$ (up to $2,500 \mathrm{mg} / \mathrm{L}$ ), $\mathrm{NiCl}_{2}$ and $\mathrm{CuSO}_{4}$ (up to $1,000 \mathrm{mg} / \mathrm{L}$ ), and $\mathrm{CoCl}_{2}$ and $\mathrm{HgCl}_{2}$ (up to $500 \mathrm{mg} / \mathrm{L}$ ). $\mathrm{IC}_{50}$ values of $\mathrm{HgCl}_{2}, \mathrm{CoCl}_{2}, \mathrm{~K}_{2} \mathrm{Cr}_{2} \mathrm{O}_{7}, \mathrm{CuSO}_{4}, \mathrm{NiCl}_{2}, \mathrm{FeSO}_{4}$, and $\mathrm{Na}_{2} \mathrm{HAsO}_{4}$ are 368, 445, 676, 1,590, 1,680, 4,403, and 7,007 mg/L, respectively (Table 2 ).

The in vitro study of plant growth-promoting activities showed that TL13 strain was able to fix atmospheric nitrogen and to solubilize phosphate. The strain TL13 has also the capacity to produce siderophores, EPS, and cellulase as materialized by the presence of transparent halo around the colony in the corresponding culture media. Furthermore, the development of a pink color following the addition of Salkowski reagent to the culture supernatant showed the capacity of TL13 to produce IAA (Figure S1). The results of antibiograms (Figure S2, Table S1) showed the resistance of TL13 strain to cefotaxime, ceftazidime (antibiotics of $\beta$-lactam group), and norfloxacin (antibiotic of fluoroquinolone group). M. metallidurans TL13 was sensitive against all other tested antibiotics. Tomato in vivo experiments revealed positive effect of the TL13 strain on seeds germination under chromium stress. In fact, with simple visual inspection, the toxic effect of high levels of chromium and the promoting effect of TL13 on seeds germination were well distinguishable (Figure 2A). Tolerance to higher chromium levels was observed with TL13-treated seeds compared to control seeds since a significant increase in shoot fresh and dry weights and shoot length were recorded (Figures 2B-D).

\section{Phylogenetic Analysis and Genomic Insights Inferred From TL13 Genome Sequence}

Based on the proposed rule of using 16S rDNA sequence similarity threshold value of $98.65 \%$ for species delineation (Kim et al., 2014), TL13 and Microbacterium proteolyticum (RZ36) should belong to the same species as their $16 \mathrm{~S}$ rDNA sequences exhibited an identity of $99.3 \%$. However, this taxonomic result was not corroborated by the phylogenetic tree (Figure 3) as both strains are not sister taxa and do not form a distinct clade for $M$. proteolyticum species. The previously mentioned taxonomical 16S rDNA value has been equated to the species delineation threshold ANI values of 95-96\% [DNA-DNA hybridization (DDH) value of 70\%] (Richter and Rosselló-Móra, 2009). TL13 exhibited 82.4 and $75.2 \%$ ANI with Microbacterium enclense NIO-1002 and Microbacterium hominis TPW29, respectively, based on JSpeciesWS. Consequently, TL13 should not belong neither to $M$. enclense nor to M. hominis species. Accordingly, TL13 is a novel species within the genus Microbacterium, 
A
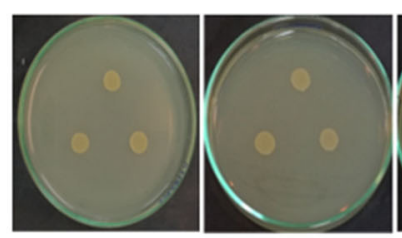

$50 \mathrm{mg} / \mathrm{L}$

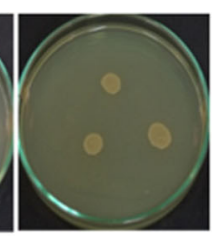

$100 \mathrm{mg} / \mathrm{L}$

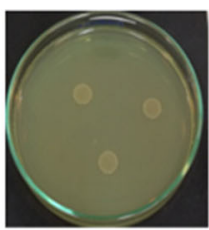

$250 \mathrm{mg} / \mathrm{L}$

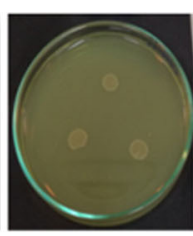

$500 \mathrm{mg} / \mathrm{L}$

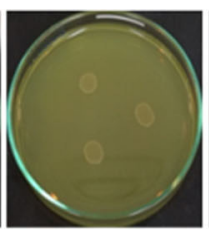

$1000 \mathrm{mg} / \mathrm{L}$

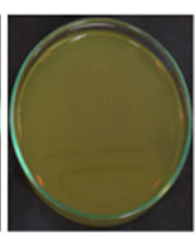

$2500 \mathrm{mg} / \mathrm{L}$

B
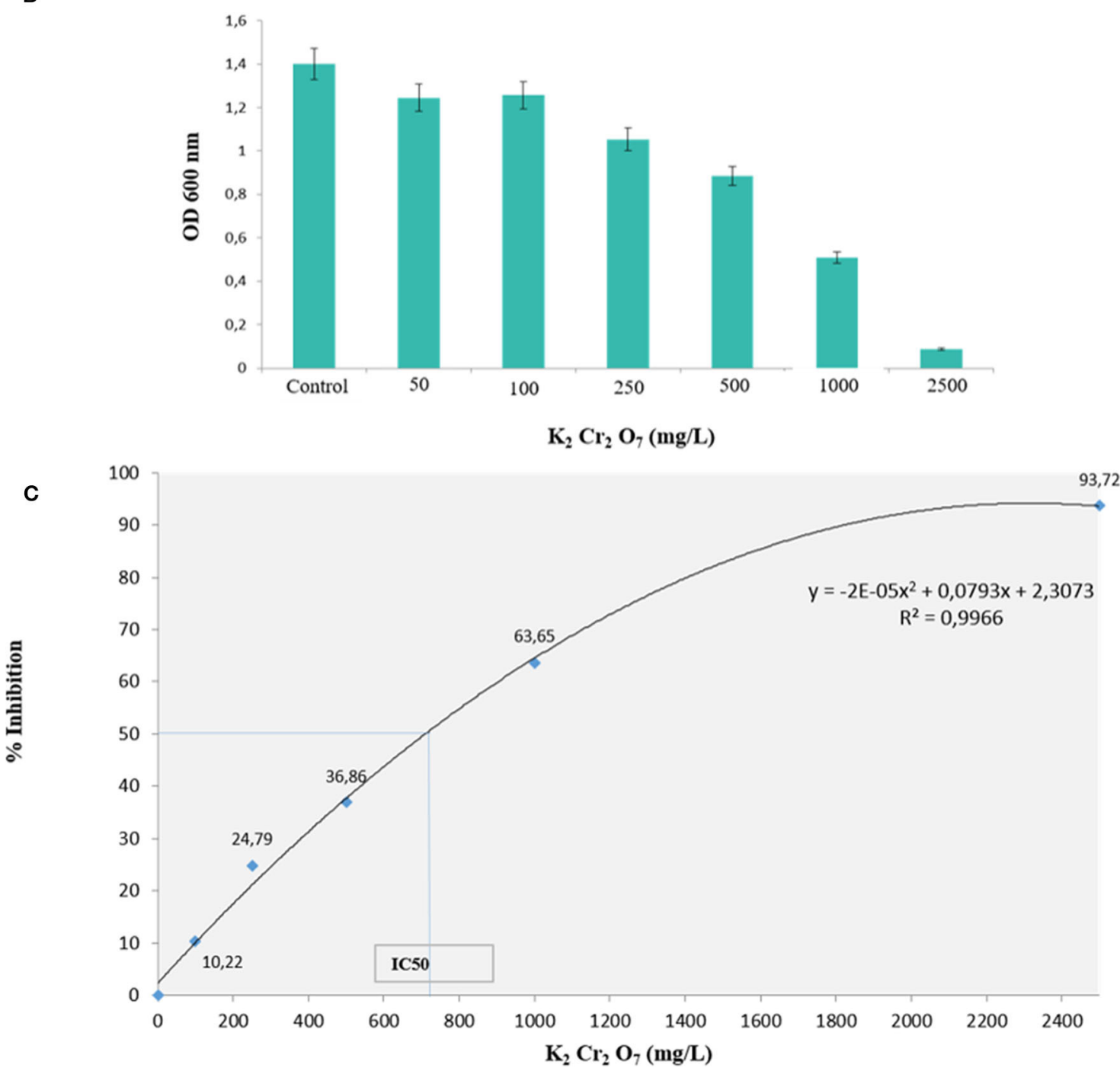

FIGURE 1 | Effect of chromium concentration on TL13 bacterial growth on (A) tryptic soy agar (TSA) medium and (B) tryptic soy broth (TSB) medium; (C) chromium dose-response curve and determination of the $\mathrm{IC}_{50}$.

for which the name M. metallidurans is proposed. Figure 4 shows the graphical representation map of the genome of TL13 strain compared with the genomes of M. enclense NIO1002 and M. hominis TPW29. The complete genome of $M$. metallidurans TL13 measured 3,587,460 bp with $70.70 \% \mathrm{G}$ $+\mathrm{C}$ content (Table 3). De novo assembly of TL13 strain genome sequencing data is represented by 5 contigs and 3,393 coding sequences.

Based on the annotation of the RAST pipeline, TL13 genes were classified into 380 subsystems revealing its high metabolic diversity. Analysis of the predicted protein sequences showed that most of the annotated genes were involved in carbohydrates 
TABLE 2 | Heavy metals resistance of TL13 strain

\begin{tabular}{lcc}
\hline \multicolumn{3}{c}{ Heavy metal resistance } \\
\hline Metal & MIC \pm SD (mg/L) & IC50 \pm SD (mg/L) \\
\hline Chromium $\left(\mathrm{K}_{2} \mathrm{Cr}_{2} \mathrm{O}_{7}\right)$ & $1,000 \pm 47$ & $676 \pm 33$ \\
Copper $\left(\mathrm{CuSO}_{4}\right)$ & $1,000 \pm 42$ & $1,590 \pm 69$ \\
Nickel $\left(\mathrm{NiCl}_{2}\right)$ & $1,000 \pm 50$ & $1,680 \pm 74$ \\
Cobalt $\left(\mathrm{CoCl}_{2}\right)$ & $500 \pm 23$ & $445 \pm 19$ \\
Iron $\left(\mathrm{FeSO}_{4}\right)$ & $2,500 \pm 113$ & $4,403 \pm 187$ \\
Mercury $\left(\mathrm{HgCl}_{2}\right)$ & $500 \pm 21$ & $368 \pm 14$ \\
Arsenic $\left(\mathrm{Na}_{2} \mathrm{HAsO}_{4}\right)$ & $2,500 \pm 107$ & $7,007 \pm 282$ \\
\hline
\end{tabular}

Data are displayed as mean SD of three independent experiments performed in triplicate.

(399), amino acids and their derivatives (354), cofactors, vitamins, prosthetic groups, pigments (214), protein metabolism (217), fatty acids, lipids and isoprenoids (129), cell membrane and capsule (91), DNA (88) and RNA (85) metabolism and response to stresses (74), virulence, defense (55), respiration (55), metabolism of aromatic compounds (47), and phosphorus metabolism (40).

Analysis of $M$. metallidurans TL13 genome revealed the presence of several genes contributing directly or indirectly to PGP activities (Table 4). Indeed, the annotation study showed the presence of genes involved in the solubilization of inorganic phosphate, assimilation of ammonia, production of levan (EPS), synthesis of IAA, siderophores and polyketides, as well as genes encoding the key cell-wall-degrading enzymes (Table 4).

The genome of $M$. metallidurans TL13 contains 32 genes related to heavy metal resistance. Based on genomic analyses, enzymatic and non-enzymatic mechanisms could be proposed to explain hexavalent chromium resistance and removal by this strain (Figure 5).

The first chromium resistance mechanism to mention is the chromate transporter protein (ChrA) encoding by fig|69370.7.peg.2330 gene and localized in contig 29. The predicted model for ChrA indicated that the enzyme is formed by $19 \alpha$-helices: $\alpha 1$ (Gly24-Val37), $\alpha 2$ (Asp45-Ala62), $\alpha 3$ (Ser64-Ala75), $\alpha 4$ (Phe77-Thr88), $\alpha 5$ (Ser91-Ala97), $\alpha 6$ (Gly101-Leu104), $\alpha 7$ (Gly107-Gly 131), $\alpha 8$ (Asp139-Ala159), $\alpha 9$ (Gly164-Ala180), $\alpha 10$ (Gly192-Leu209), $\alpha 11$ (Ala227-Glu251), a12 (Ser259-Val273), $\alpha 13$ (Pro276-Gly285), $\alpha 14$ (Val295Val303), $\alpha 15$ (Leu307-Leu323), $\alpha 16$ (Gly335-Leu348), $\alpha 17$ (Pro360-Phe363), a18 (Ala366-Phe376), and a19 (Val384Leu396) (Figure 5B).

The second gene potentially involved in the bacterial chromium reduction by TL13 strain is the superoxide dismutase with a molecular weight of $23,177.87 \mathrm{Da}$, encoded by the gene fig|69370.7.peg.2482. The superoxide dismutase predicted model indicated that this enzyme belongs to the metalloenzyme family (EC1.15.1.1), which is composed of seven $\alpha$-helices $(\alpha 1$, Thr23-Lys53; $\alpha 2$, Arg61-Thr81; $\alpha 3$, Asp94-Asp100; $\alpha 4$, Asp107Gly119; $\alpha 5$, His164-Tyr170; $\alpha 6$, Ala175-Asn183; and $\alpha 7$, Asp $189-$ Arg198), three-stranded antiparallel $\beta$ sheets ( $\beta 1$, Gly124Asp131; $\beta 2$, Asn136-Phe143; and $\beta 3$, Val154-Asp160), and loops joining these secondary structure elements. The monomer structure of the enzyme contains two domains: the rod-shaped Nterminal domain ( $\mathrm{N}$-terminal extended region and two $\alpha$-helices) and the globular $(\alpha+\beta)$-type $\mathrm{C}$-terminal domain (Figure 5C). The active site is composed of His28, His76, Asp160, and His164 (Figure 5D).

According to genome analyses, the glutathione peroxidase could also be involved in chromium reduction. This enzyme, with a molecular weight of $17,787.16 \mathrm{Da}$ and an isoelectric point of 5.66, is encoded by the gene fig|69370.7.peg.2340. The gene is localized on the contig 4 . The predicted model for glutathione peroxidase indicated that its structure is composed of seven $\beta$ strands ( $\beta 1$, Pro7-Thr10; $\beta 2$, Gly13-Thr17; $\beta 3$, Ala26Val32; $\beta 4$, Phe57-Pro63; $\beta 5$, Met91-Ser92; $\beta 6$, Lys128-Phe132; and $\beta 7$, Gly135-Phe140), four $\alpha$-helices ( $\alpha 1$, Gln41-Arg55; $\alpha 2$, Glu74-Trp85; $\alpha 3$, Pro104-Thr112; and $\alpha 4$, Pro149-Pro160), and loops joining these elements together. The structural analysis demonstrated that (i) the N-terminal end is formed by two $\beta$ strands ( $\beta 1$ and $\beta 2$ ), (ii) the enzyme contains central twisted $\beta$ sheets $(\beta 3, \beta 4, \beta 5, \beta 6$, and $\beta 7)$ boarded by helices $\alpha 1, \alpha 2$, and $\alpha 4$ on one side and helix $\alpha 3$ on the other side, and (iii) the $\mathrm{C}$-terminal end is composed of helix $\alpha 4$, which is nearly parallel with the $\alpha 1$. The model contains 161 residues from Met1 to His161, and the amino acid residues of the catalytic triad are Cys36, Gln70, and Trp124 (Figure 5E).

The TL13 genome analysis revealed also the presence of three genes encoding thioredoxin reductases (fig|69370.7.peg.1744 and fig|69370.7.peg.1847 localized on the contig 29 and fig|69370.7.peg.2708 localized on the contig 45). The predicted model for the thioredoxin reductase encoded by gene (fig|69370.7.peg.1847) indicated that the structure is composed of seven $\alpha$-helix $\alpha 1$ (Gly10-Met23) $\alpha 2$ (Leu57-Ala67), a3 (Ala119-Arg124), $\alpha 4$ (Gly134-Phe137), $\alpha 5$ (Pro149Val161), $\alpha 6$ (Phe210-214), and $\alpha 7$ (Leu256-Pro277) and $15 \beta$ strands $\beta 1$ (Ala4-Ile6), $\beta 2$ (Thr27-Leu29), $\beta 3$ (Val71-Ile73), $\beta 4$ (Ser79-Ala82), $\beta 5$ (Val88-Val92), $\beta 6$ (Glu 95-Ala99), $\beta 7$ (Tyr101-Leu104), $\beta 8$ (Val126-Ala127), $\beta 9$ (Ala143-Val144), $\beta 10$ (Val166-Val167), $\beta 11$ (Val173-Arg175), $\beta 12$ (Thr186Leu187), $\beta 13$ (Gly190-Thr192), $\beta 14$ (Ala198-Phe199), and $\beta 15$ (Leu238-Ala239). The structure is composed of the flavin adenine dinucleotide (FAD)-binding domain (Ser32, Glu 34, Tyr35, Val40, Ala43, Val 78, Thr106, Gly 107, Cys 132, Arg 207, Thr 255, Leu 256) and the reduced nicotinamide adenine dinucleotide phosphate (NADPH)-binding domain (Pro114, Ala147, Ser148, His 150, Lys153, Val203, His 248) (Figure 5F). The predicted model of the thioredoxin indicated that the $\mathrm{N}$-terminal domain is composed of three $\beta$ strands $\beta^{\prime}$ (Ala17Val18), $\beta^{\prime \prime}$ (Arg25-Arg26), and $\beta^{\prime \prime \prime}$ (Gln28-Gly29). The central structure is composed of five $\beta$ strands $[\beta 1$ (Glu38-Ileu39), $\beta 2$ (Thr55-Ser60), $\beta 3$ (Arg85-Asp90), $\beta 4$ (Thr108-Asp113), and $\beta 5$ (Gly116-Phe122)] surrounded by four $\alpha$-helices $(\alpha 1$ (Pro42-Leu50), $\alpha 2$ (Arg66-Asp80), $\alpha 3$ (Leu91-His100), and $\alpha 4$ (Gly127-Ala143). It displays a strictly conserved CXXC catalytic active-site motif (Figure 5G). In addition to the abovementioned mechanisms, $M$. metallidurans TL13 can protect itself from the infiltration of toxic chromium ions by covering its peripheral surface with a shield of levan, a fructose homopolysaccharide, which can be synthesized by levan sucrase 


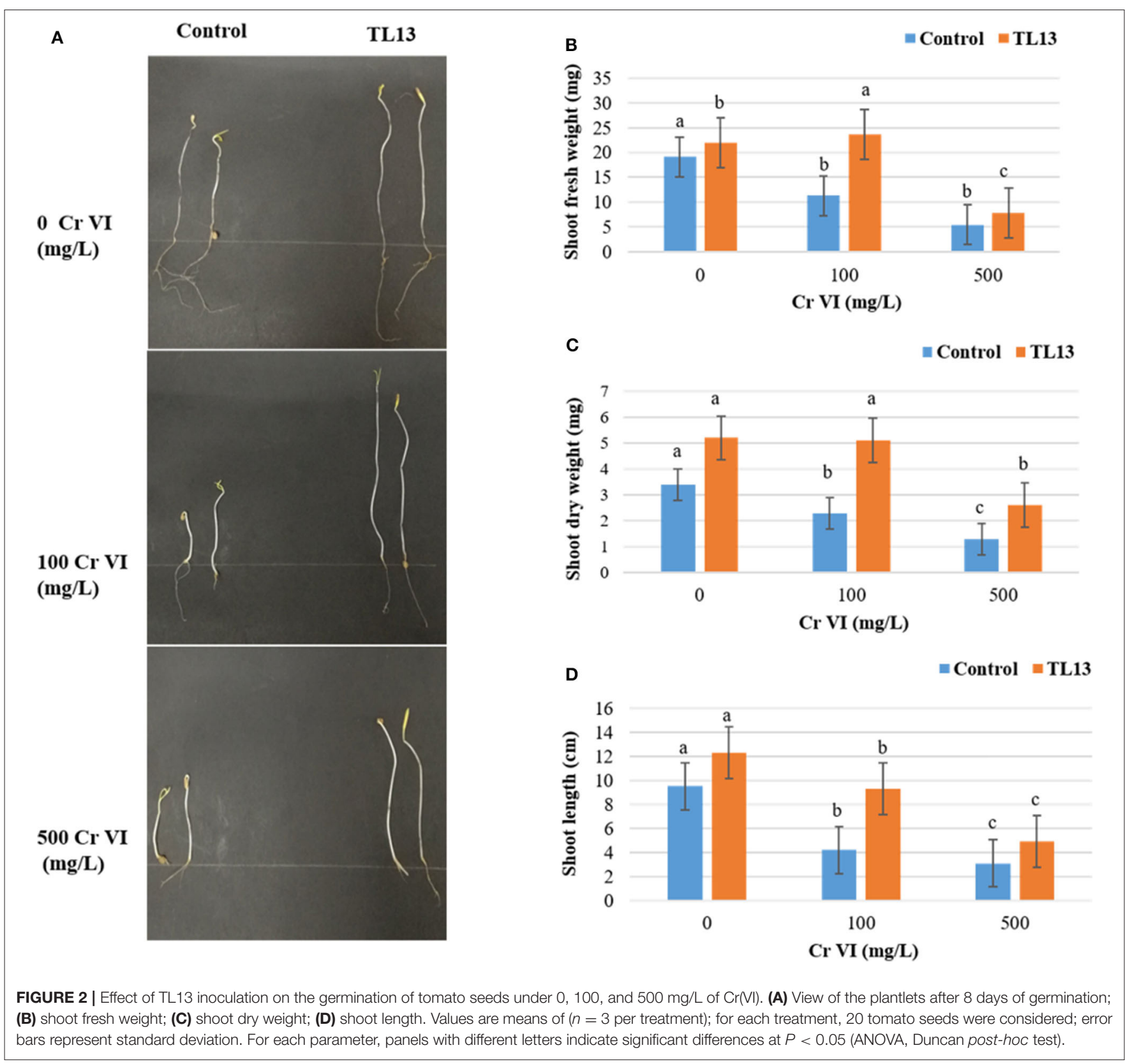

(fig|69370.7.peg.1075). Bioaccumulation might represent a supplementary route to achieve chromium resistance by TL13.

\section{DISCUSSION}

Bacteria of the genus Microbacterium (phylum of Actinobacteria) include more than 110 cultivable species (http://www.bacterio. net/microbacterium.html) isolated from aquatic and terrestrial ecosystems and from food and clinical samples. Figure S3 illustrates the microbial world (according to the Gold and DSMZ databases) with each point representing a type of bacterial strain, and if applicable, the associated ongoing sequencing projects (colored red). As shown in Figure S3, many taxonomic groups still need to be explored at the genomic level and, in particular, the Microbacterium group for which only few genomes are available (https://microbial-earth.namesforlife.com/). Several Microbacterium members have been isolated from extreme environments ( $\mathrm{Li}$ et al., 2008) or contaminated with organic pollutants (Schippers et al., 2005) and metals such as uranium (Reardon et al., 2004; Gallois et al., 2018), plutonium and iron(III) (John et al., 2001), arsenic (Cai et al., 2009), and chromium (Pattanapipitpaisal et al., 2001; Humphries et al., 2005).

There are only few studies reported in the literature on the predominance and ecological importance of bacterial populations of the genus Microbacterium as PGPB (Alves et al., 2015; Gao et al., 2017). Although such bacteria directly stimulate 


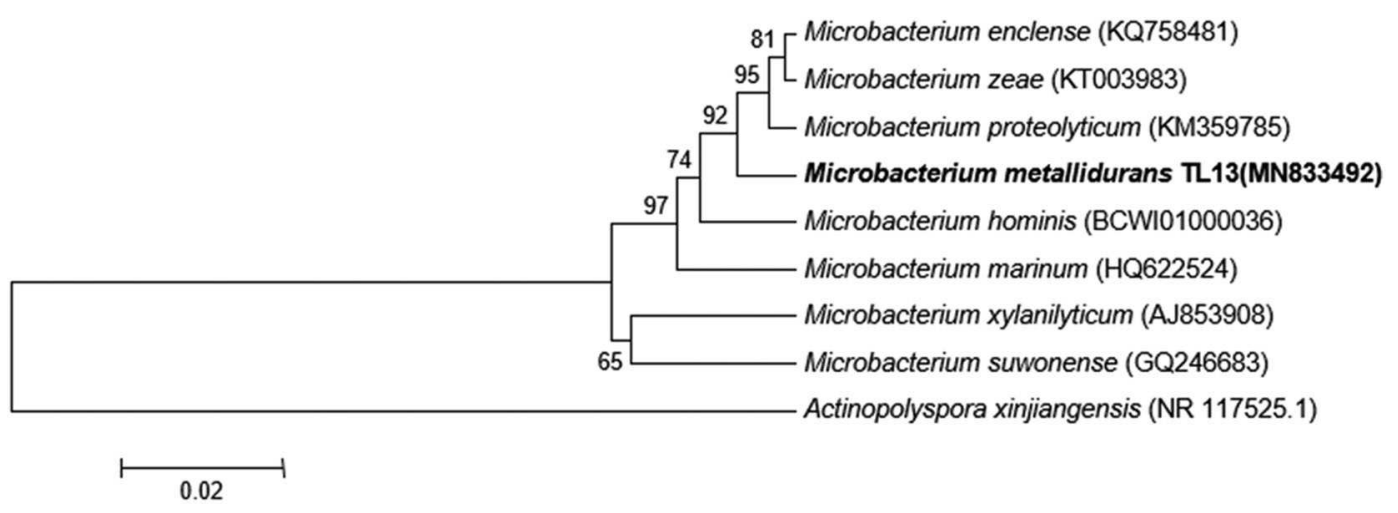

FIGURE 3 | Phylogenetic tree highlighting the position of $M$. metallidurans TL13 among related taxa within the genus Microbacterium based on 16S rDNA gene sequences. Evolutionary distances were calculated using the method of maximum composite likelihood, and the topology was inferred using the neighbor-joining method using MEGA 7. Numbers on the nodes present \% bootstrap values based on 500 replicates. Scale bar represents 0.02 substitutions per site. The $16 S$ rDNA gene sequence of Actinopolyspora xinjiangensis was arbitrarily chosen as the outgroup to define the root of the tree.

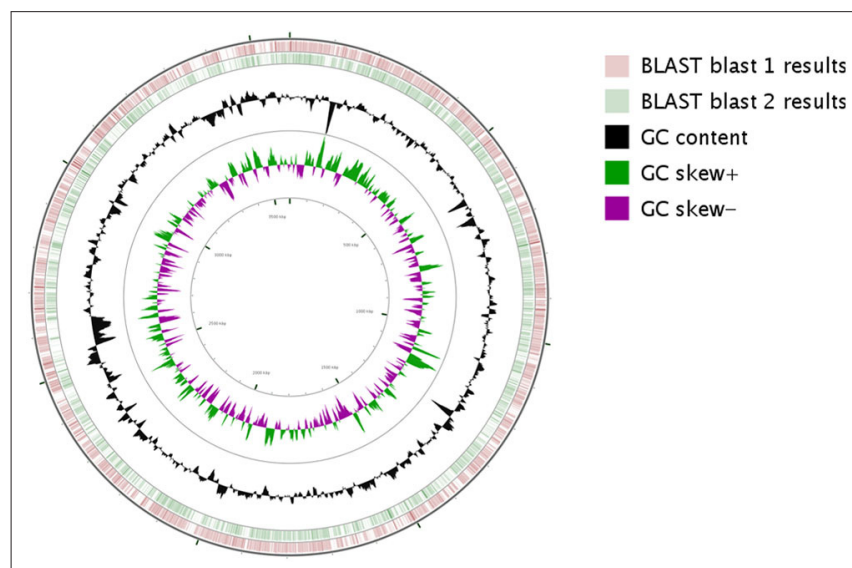

FIGURE 4 | Circular representation of M. metallidurans TL13 genome generated by CG viewer. The innermost rings depict GC content (Black) and GC Skew (purple/green) followed by concentric rings of query sequences colored according to BLAST identity. The outermost rings depict genomes of the following microbes $M$. enclense $\mathrm{NIO}-1002$ (pink) and M. hominis TPW29 (green).

plant growth by increasing soil nutrient uptake, inducing and producing plant growth regulators, and activating induced resistance mechanisms in plants, special attention has recently been given to bioremediation of organic and inorganic pollutants by PGPB (Bishnoi, 2015). Therefore, the present study aimed to characterize a new heavy-metal-resistant PGPB isolated from a Tunisian tannery wastewater for potential application as a green and sustainable tool for decreasing accumulation of metals in industrial sludges and wastewaters and in plant rhizosphere and tissues.

The actinobacterium TL13 exhibited resistance to all of the tested heavy metal ions. The half inhibitory concentration values of mercury, cobalt, chromium, copper, nickel, iron, and arsenic were $368,445,676,1,590,1,680,4,403$, and 7,007 mg/L, respectively, and their toxic order was $\mathrm{HgCl}_{2}>\mathrm{CoCl}_{2}>$
TABLE 3 | Characteristics of Microbacterium metallidurans TL13 genome.

\begin{tabular}{lc}
\hline Genome & Microbacterium metallidurans TL13 \\
\hline $\begin{array}{l}\text { Domain } \\
\text { Taxonomy }\end{array}$ & Bacteria \\
& Actinobacteria; Actinobacteria; \\
& Micrococcales; Microbacteriaceae; \\
& Microbacterium; Microbacterium \\
metallidurans TL13
\end{tabular}

$\mathrm{K}_{2} \mathrm{Cr}_{2} \mathrm{O}_{7}>\mathrm{CuSO}_{4}>\mathrm{NiCl}_{2}>\mathrm{FeSO}_{4}>\mathrm{Na}_{2} \mathrm{HAsO}_{4}$. TL13 possesses in vitro PGP traits including nitrogen fixation and inorganic phosphate solubilisation as well the production of PGP metabolites like IAA, siderophore, EPS, and cellulases. The growth-promoting capacity of TL13 strain was confirmed in vivo by measuring shoots length and fresh and dry weight of tomato seedlings in the presence of increasing chromium concentrations. Inoculation of TL13 to tomato increased plant growth by $22.77 \%$ of shoot length, $12.79 \%$ of fresh weight, and $34.62 \%$ of dry weight.

The whole genome of TL13 strain was sequenced and annotated in order to provide information on genomic elements related to heavy metal resistance and plant growth-promoting traits. The genome consists of 3,587,460 bp with an average GC content of $70.7 \%$ and a total of 52 genes encoded RNAs. Of the 3,393 genes predicted, 2,425 were identified as genes encoding proteins (genes had a specific function) and 968 genes (28.53\%) were classified as hypothetical proteins (genes without function prediction). The ANI values between the strain TL13 and the 
TABLE 4 | Rapid Annotations using Subsystems Technology (RAST) predicted proteins potentially associated with plant growth promotion traits within the genome of Microbacterium metallidurans TL13.

\begin{tabular}{|c|c|c|c|c|}
\hline Protein name & Start & Stop & Length (pb) & Feature ID \\
\hline \multicolumn{5}{|l|}{ Ammonia assimilation } \\
\hline Ammonium transporter & 28,180 & 26,909 & 1,272 & fig|69370.7.peg.113 \\
\hline Glutamine synthetase type I (EC 6.3.1.2) & 68,639 & 70,063 & 1,425 & fig|69370.7.peg.148 \\
\hline Glutamate-ammonia-ligase adenylyltransferase (EC 2.7.7.42) & 78,333 & 75,340 & 2,994 & fig|69370.7.peg.153 \\
\hline Glutamine synthetase type I (EC 6.3.1.2) & 79,681 & 78,341 & 1,341 & fig|69370.7.peg.154 \\
\hline Glutamate synthase [NADPH] small chain (EC 1.4.1.13) & 256,192 & 254,726 & 1,467 & fig|69370.7.peg.2590 \\
\hline Glutamate synthase [NADPH] large chain (EC 1.4.1.13) & 260,762 & 256,185 & 4,578 & fig|69370.7.peg.2591 \\
\hline \multicolumn{5}{|l|}{ Inorganic phosphate assimilation and solubilization } \\
\hline \multirow[t]{2}{*}{ Probable low-affinity inorganic phosphate transporter } & 276,078 & 277,253 & 1,176 & fig|69370.7.peg.349 \\
\hline & 87,776 & 86,481 & 1,296 & fig|69370.7.peg.2726 \\
\hline \multirow[t]{3}{*}{ Phosphate regulon transcriptional regulatory protein PhoB (SphR) } & 695,530 & 696,507 & 978 & fig|69370.7.peg.2090 \\
\hline & $11,84,663$ & $11,85,424$ & 762 & fig|69370.7.peg.1222 \\
\hline & 750,067 & 749,384 & 684 & fig|69370.7.peg.804 \\
\hline \multirow[t]{3}{*}{ Phosphate ABC transporter, periplasmic phosphate-binding protein PstS (TC 3.A.1.7.1) } & 766,996 & 768,117 & 1,122 & fig|69370.7.peg.821 \\
\hline & 848,746 & 847,049 & 1,698 & fig|69370.7.peg.902 \\
\hline & 860,264 & 858,657 & 1,608 & fig|69370.7.peg.910 \\
\hline Phosphate regulon sensor protein PhoR (SphS) (EC 2.7.13.3) & 751,281 & 750,064 & 1,218 & fig|69370.7.peg.805 \\
\hline Inorganic pyrophosphatase (EC 3.6.1.1) & 941,934 & 942,467 & 534 & fig|69370.7.peg.2325 \\
\hline Exopolyphosphatase (EC 3.6.1.11) & 626,058 & 627,020 & 963 & fig|69370.7.peg.2018 \\
\hline
\end{tabular}

\section{Auxin synthesis}

Tryptophan synthase alpha chain (EC 4.2.1.20) involved in auxin synthesis

Tryptophan synthase beta chain (EC 4.2.1.20) involved in auxin synthesis

Anthranilate phosphoribosyltransferase (EC 2.4.2.18)

phosphoribosylanthranilate isomerase (EC 5.3.1.24)

Monoamine oxidase (1.4.3.4)

262,621

263,952

68,751

262,621

885,447

833,234

\section{Siderophore synthesis}

Siderophore -interacting protein

$\mathrm{ABC}$-type $\mathrm{Fe}^{3+}$-siderophore transport system, permease 2 component

ABC-type $\mathrm{Fe}^{3+}$-siderophore transport system, ATPase component

ABC-type $\mathrm{Fe}^{3+}$-siderophore transport system, permease 2 component

$\mathrm{ABC}$-type $\mathrm{Fe}^{3+}$-siderophore transport system, permease component

Putative ABC iron siderophore transporter, fused permease and ATPase domains

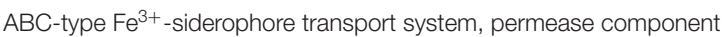

Putative ABC iron siderophore transporter, fused permease and ATPase domains

Potent fungal cell-wall-degrading enzymes

Carboxymethyl cellulase (EC 3.2.1.4)

Serine protease, subtilase family (EC 3.4.21.-)

Putative serine protease

$\beta$-hexosaminidase (EC 3.2.1.52)

\section{Exopolysaccharide synthesis}

Levansucrase (EC 2.4.1.10)

Polyketide Synthesis

Regulator of polyketide synthase expression

Malonyl CoA-acyl carrier protein transacylase (EC 2.3.1.39)

3-oxoacyl-[acyl-carrier-protein] synthase, KASIII (EC 2.3.1.41)

Acyl carrier protein

3-oxoacyl-[acyl-carrier-protein] synthase, KASII (EC 2.3.1.179)

Chalcone synthase (EC 2.3.1.74)

\begin{tabular}{|c|c|c|}
\hline 261,830 & 792 & fig|69370.7.peg.2593 \\
\hline 262,618 & 1,335 & fig|69370.7.peg.2594 \\
\hline 69,812 & 1,062 & fig|69370.7.peg.2400 \\
\hline 261,830 & 792 & fig|69370.7.peg.2593 \\
\hline 887,435 & 1,989 & fig|69370.7.peg.931 \\
\hline 831,207 & 2,028 & fig|69370.7.peg.2215 \\
\hline 180,231 & 927 & fig|69370.7.peg.2511 \\
\hline 778,700 & 1,008 & fig|69370.7.peg.832 \\
\hline 180,313 & 8,25 & fig|69370.7.peg.2512 \\
\hline 181,134 & 1,059 & fig|69370.7.peg.462 \\
\hline 182,189 & 1,047 & fig|69370.7.peg.661 \\
\hline 403,672 & 1,818 & fig|69370.7.peg.3014 \\
\hline 777,696 & 981 & fig|69370.7.peg.831 \\
\hline 587,765 & 762 & fig|69370.7.peg.647 \\
\hline 695,393 & 954 & fig|69370.7.peg.868 \\
\hline 15,790 & 3,573 & fig|69370.7.peg.1452 \\
\hline 479,579 & 1,176 & fig|69370.7.peg.534 \\
\hline 603,559 & 1,155 & fig|69370.7.peg.3342 \\
\hline 103,277 & 1,881 & fig|69370.7.peg.534 \\
\hline 647,819 & 1,608 & fig|69370.7.peg.1075 \\
\hline 96,821 & 1,272 & fig|69370.7.peg.171 \\
\hline 97,824 & 921 & fig|69370.7.peg.172 \\
\hline 98,825 & 1,005 & fig|69370.7.peg.173 \\
\hline 99,148 & 249 & fig|69370.7.peg.174 \\
\hline 100,452 & 1,239 & fig|69370.7.peg.175 \\
\hline 913,969 & 1,095 & fig|69370.7.peg.956 \\
\hline
\end{tabular}



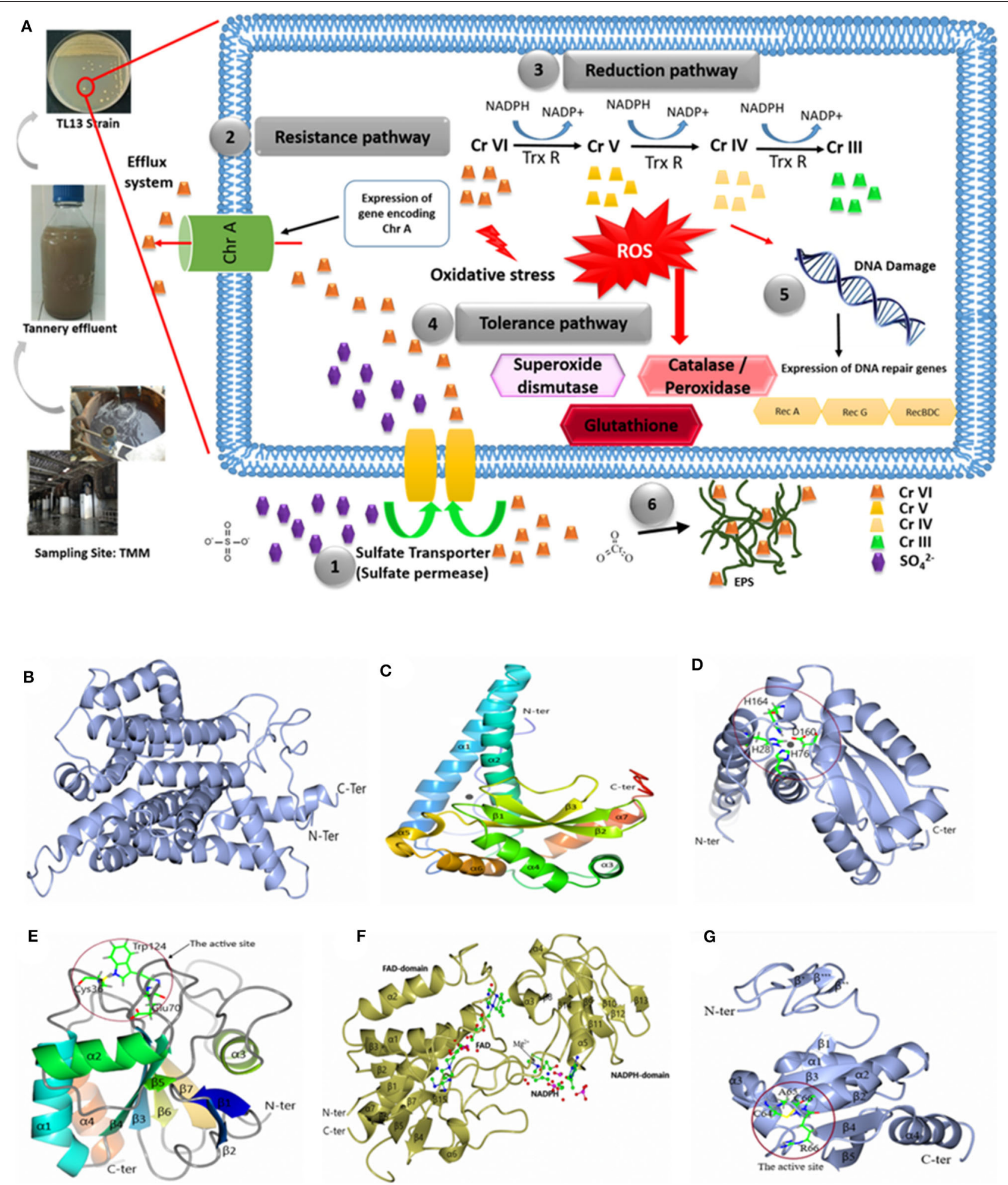

FIGURE 5 | (A) Hypothetical pathways involved in chromium resistance and reduction in M. metallidurans TL13: (1) The sulfate permease allows chromium to get into bacterial cell; (2) expression of gene encoding chromate transporter ChrA (Efflux system); (3) reduction of chromium due to thioredoxin reductase and NADPH; (4) oxidative stress due to chromium reduction [Cr(M) and $\mathrm{Cr}(\mathrm{IV})]$ induced reactive oxygen species (ROS): superoxide dismutase, catalase, peroxidase, and glutathione; (5) DNA damage: expression of dna repair genes (RecA, RecG, and RecBDC); and (6) exopolysaccharides (EPS) and metal complex. Cartoon representation of 3D structure of TL13: (B) chromate transporter; (C) superoxide dismutase; (D) the active site of superoxide dismutase; (E) glutathione peroxidase with the localization of the active site; (F) thioredoxin reductase with the localization of reduced nicotinamide adenine dinucleotide phosphate (NADPH) and flavin adenine dinucleotide (FAD) domain, and (G) 3D structure of TL13 thioredoxin with the localization of the active site. 
closely related strains were $76.5-82.7 \%$, indicating that TL13 strain is a novel species of the genus Microbacterium.

Functional annotation of TL13 genome revealed the presence of genes encoding proteins involved in resistance to metal stress, such as cobalt-zinc-cadmium resistance protein, copper resistance protein, copper responsive transcriptional regulator, arsenical resistance operon repressor, arsenate reductase, arsenic resistance protein, mercuric resistance operon regulatory protein, mercuric ion reductase, and organomercurial lyase. The TL13 genome analysis revealed also the presence of different potential genes involved in chromium reduction such as chromate transporter, superoxide dismutase, glutathione peroxidase, and the thioredoxin reductase. The chromate transporter protein (ChrA) has been reported to play a crucial role in efflux of cytoplasmic chromate (Alvarez et al., 1999; Ahemad and Kibret, 2014). The participation of bacterial enzymes in the defense against oxidative stress induced by chromate represents an additional mechanism of chromate resistance (McCord and Fridovich, 1988; Ackerley et al., 2006; Ramirez-Diaz et al., 2008). The TL13 strain has the potential to have a powerful enzyme system to combat oxidative stress involving catalase (EC 1.11.1.6), glutathione peroxidase, and superoxide dismutase [Mn] (EC 1.15.1.1). The theriodixin reductase, an $\mathrm{Mg}^{2+}$. dependent enzyme, is also involved in the reduction in $\mathrm{Cr}(\mathrm{VI})$ (Li and Krumholz, 2009; Collet and Messens, 2010). The two cysteines of the catalytic motif (Cys64, A65, R66, Cys67), located at the amino end of the two-helix, are the key players involved in the reduction of oxidized substrates. Chen et al. (2014) reported that the entire operon of thioredoxin of Streptomyces violaceoruber strain LZ-26-1 was upregulated under the stress of $\mathrm{Cr}(\mathrm{VI})$. This result suggests that TL13 strain can use thioredoxin pathway to reduce $\mathrm{Cr}(\mathrm{VI})$. Various oxidoreductases have been shown to reduce $\mathrm{Cr}(\mathrm{VI})$ such as ChrR from E. coli and Pseudomonas and NfsA from E. coli (Ackerley et al., 2004). Genes coding for $\mathrm{Cr}(\mathrm{VI})$-reducing oxidorecductase were not detected on TL13 genome. This result probably shed light on novel Cr(VI) reductases within the thioredoxin pathway.

M. metallidurans TL13 was able to produce levan based on genomic signature (presence of the gene encoding levan sucrase) linked to experimental evidence (mucoid phenotype on agar plate). The anionic property of the EPS enables it to trap the positively charged chromium by electrostatic interaction and hence playing a key role as biosorbents for metal remediation (Harish et al., 2012; Gupta and Diwan, 2017).

TL13 genome encodes an efficient framework for iron acquisition mediated by a siderophore-dependent pathway as similar to that of Cupriavidus metallidurans CH34 (Tables S2, S3). Iron is essential for vital processes including DNA, RNA, and protein synthesis, electron transport, cell respiration and proliferation, as well as gene expression regulation. Iron has the ability to easily acquire and lose electrons from the iron form $\mathrm{Fe}^{2+}$ to the iron form $\mathrm{Fe}^{3+}$, and vice versa. This rather unique property gives it an essential role in oxidation and reduction processes. The chemical properties of iron make it potentially toxic. When iron is in limited supply, TL13 can produce and secrete siderophores capable of chelating ferric $\mathrm{Fe}^{3+}$ with very high affinity. The siderophore-Fe ${ }^{3+}$ complexes are then recovered by the bacterium using specific membrane transporters. The dissociation of iron from its chelator generally requires a reduction in $\mathrm{Fe}^{3+}$ to $\mathrm{Fe}^{2+}$ and a structural modification of the siderophore, making it less affine for the metal (Payne et al., 2016; Li and Ma, 2017).

Besides these genes conferring resistance to metal and oxidative stresses identified in TL13 genome, the RAST analysis showed the presence of 10 genes involved in osmoadaptation, in particular in the biosynthesis of betaine and choline osmolytes, 14 proteins (operon $d n a K$ ) to fight against thermal stress, and 4 against cold (proteins from the CspA family). Analysis of the genome of $M$. metallidurans TL13 revealed also the presence of 118 genes involved in different pathways of central carbohydrate metabolism like the tricarboxylic acid cycle and the pentose phosphate pathway. It also indicated the presence of 43 proteins involved in anaerobic fermentation processes. The genome of $M$. metallidurans TL13 codes for exopolyphosphatase (EC 3.6.1.11), inorganic manganese-dependent pyrophosphatase (EC 3.6.1.1), and low affinity inorganic phosphate carriers, which play a crucial role in phosphorus cycle by solubilizing its inorganic form that is fixed and precipitated in the soil (Al-Kaisi et al., 2013; Bhattacharyya et al., 2017). Moreover, the genome of M. metallidurans TL13 encodes all the genes necessary for ammonia assimilation and plant auxin biosynthesis (Spaepen and Vanderleyden, 2011). Several Microbacterium strains isolated from rhizospheric and non-rhizospheric environments are able to fix nitrogen, as confirmed by acetylene-reducing activity and PCR amplification of nifH gene (Gtari et al., 2011). Whereas, some nitrogen-fixing bacteria are able to produce nitrogenases with iron as the only metal cofactor, other bacterial strains incorporate molybdenum or vanadium into the cofactor as well (Johnstone and Nolan, 2015). For the strain TL13, a search for nitrogenase systems merits further investigation at the genome and physiological levels.

Besides these direct PGP traits, several genes involved in the biocontrol of phytopathogens exist in the genome of M. metallidurans TL13, including genes coding for cell-walldegrading enzymes (cellulose, $\beta$-hexosaminidase, and proteases) (Dutta and Thakur, 2017) and genes coding enzymes responsible for the biosynthesis of polyketides, a class of secondary metabolites with antimicrobial roles (Khanna et al., 2019). M. metallidurans TL13 showed resistance to $\beta$-lactams and fluoroquinolones antibiotics leading to improved chance of survival in a competitive rhizospheric soil (Bhattacharyya et al., 2017). All genomic plant growth-promoting features make TL13 strain an excellent actinobacterium for utilization in sustainable agriculture (Table 5). Overall, these PGP results were in line with those reported for Microbacterium sp. strain 3J1 (Manzanera et al., 2015), Microbacterium sp. Yaish 1 (Jana et al., 2017), and Microbacterium hydrothermale BPSAC84 (Passari et al., 2019b).

\section{CONCLUSION}

This study reports the characterization of a heavy-metalresistant, plant growth-promoting actinobacterium, $M$. 
TABLE 5 | Genomic features and biotechnological potential of M. metallidurans TL13 compared to other Microbacterium species.

\begin{tabular}{|c|c|c|c|c|c|c|}
\hline Strain & Origin & $\begin{array}{c}\text { Genome } \\
\text { length (Mb) }\end{array}$ & $\begin{array}{l}\text { GC } \\
(\%)\end{array}$ & $\begin{array}{l}\text { Pathways and genes of } \\
\text { interest }\end{array}$ & Bioremediation potential & References \\
\hline $\begin{array}{l}\text { M. oleivorans strain } \\
\text { Wellendorf }\end{array}$ & $\begin{array}{l}\text { Hydrocarbon- } \\
\text { contaminated } \\
\text { soil }\end{array}$ & 2.92 & 69.57 & $\begin{array}{l}\text { 4-hydroxyphenylacetate } \\
\text { degradation; Nitronate } \\
\text { detoxification }\end{array}$ & $\begin{array}{l}\text { Environmental pollutants } \\
\text { detoxification }\end{array}$ & $\begin{array}{l}\text { Avramov et al., } \\
2016\end{array}$ \\
\hline Microbacterium sp. A20 & $\begin{array}{l}\text { Heavy metal } \\
\text { contaminated soil } \\
\text { (Indiana, USA) }\end{array}$ & 3.94 & 68.53 & $\begin{array}{l}\text { Co/Zn/Cd efflux system; } \\
\text { Tolerance to antibiotics; } \\
\text { Chromium reductase (chrR) }\end{array}$ & $\begin{array}{l}\text { Reduction of Cr VI into Cr III; } \\
\text { Tolerance of cobalt, cadmium, } \\
\text { and nickel }\end{array}$ & $\begin{array}{l}\text { Learman et al., } \\
2019\end{array}$ \\
\hline Microbacterium sp. K19 & & 3.89 & 68.69 & & & \\
\hline Microbacterium sp. K21 & & 3.85 & 68.33 & & & \\
\hline M. oxydans BEL4b & $\begin{array}{l}\text { Rhizosphere of } \\
\text { Brassica napus } \\
\text { (Belgium) }\end{array}$ & 3.8 & 68.27 & $\begin{array}{l}\text { Heavy metals resistance; } \\
\text { Production of terpenoids } \\
\text { Production of polyketides }\end{array}$ & $\begin{array}{l}\text { Promoting plant growth in } \\
\text { heavy metals contaminated } \\
\text { soils }\end{array}$ & $\begin{array}{l}\text { Corretto et al., } \\
2015\end{array}$ \\
\hline M. Azadirachtae ARN176 & $\begin{array}{l}\text { Heavy metals } \\
\text { contaminated Soil } \\
\text { (Austria) }\end{array}$ & 3.91 & 70.14 & & & \\
\hline $\begin{array}{l}\text { M. laevaniformans Strain } \\
\text { OR221 }\end{array}$ & $\begin{array}{l}\text { Field Research } \\
\text { Center (Tennessee, } \\
\text { USA) }\end{array}$ & 3.4 & 68 & $\begin{array}{l}\text { Heavy-metal transport } \\
\text { proteins }\end{array}$ & $\begin{array}{l}\text { Tolerance of heavy metals and } \\
\text { acidic conditions }\end{array}$ & $\begin{array}{l}\text { Brown et al., } \\
2012\end{array}$ \\
\hline M. testaceum StLB037 & $\begin{array}{l}\text { Potato leaves } \\
\text { (Japan) }\end{array}$ & 3.98 & 70.28 & Lactonases genes & $\begin{array}{l}\text { Biocontrol agent against } \\
\text { phytopathogens }\end{array}$ & $\begin{array}{l}\text { Morohoshi et al., } \\
2011\end{array}$ \\
\hline M. profundi Shh49 & $\begin{array}{l}\text { Sea sediment } \\
\text { (Pacific Ocean) }\end{array}$ & 3.36 & 66.54 & $\begin{array}{l}\text { Multicopper oxidases (MCOs); } \\
\text { Mercuric reductase }\end{array}$ & $\begin{array}{l}\text { Reduction of mercury in } \\
\text { contaminated environments }\end{array}$ & Wu et al., 2015 \\
\hline M. metallidurans TL13 & $\begin{array}{l}\text { Tannery wastewater } \\
\text { (Tunisia) }\end{array}$ & 3.58 & 70.7 & $\begin{array}{l}\text { Genes involved in heavy metal } \\
\text { resistance and plant growth } \\
\text { promotion }\end{array}$ & $\begin{array}{l}\text { Bioremediation of tannery } \\
\text { wastewater and metal } \\
\text { contaminated soil; Plant } \\
\text { growth promotion under } \\
\text { metallic stress }\end{array}$ & This work \\
\hline
\end{tabular}

metallidurans TL13, isolated from a tannery effluent. Genome analyses, as well as experimental studies, indicated that M. metallidurans TL13 could promote plant growth, especially by solubilizing inorganic phosphate, synthesizing siderophores, and producing IAA, hydrolytic enzymes, and EPS. Besides, genome annotation revealed the presence of multiple genetic determinants related to the resistance to heavy metals, particularly chromium, arsenic, and mercury. To the best of our knowledge, this is the first report providing new insights into the molecular mechanisms underlying the enhancement of plant growth and the resistance to chromium and other heavy metals in a new species of Microbacterium. Further comparative genomic analysis and direct redox experimentation will provide additional information about the variance and pathways involved in the multimetal resistance and rhizosphere bioremediation by the actinobacterium $M$. metallidurans TL13 that is expected to facilitate environmental and agricultural applications in heavy metal-polluted sites.

\section{DATA AVAILABILITY STATEMENT}

The Whole Genome Shotgun project has been deposited at DDBJ/ENA/GenBank under the accession SZZQ00000000. The version reported in this work is SZZQ01000000.

\section{AUTHOR CONTRIBUTIONS}

$\mathrm{MN}$, RO, HCho, and AChe conceived and designed the experiments. HChe, YB, and RO performed PGP experiments. ACha and HK performed chemical analysis. AN, HS, RO, AM, $\mathrm{MM}$, and MN performed bioinformatics and structural analysis. $\mathrm{HK}$ contributed reagents, material tools. $\mathrm{MN}, \mathrm{RO}, \mathrm{AO}, \mathrm{AN}$, HChe, MM, AM, HS, HCho, and AChe analyzed the data. RO, AO, MM, AN, MN, HS, HChe, and AChe prepared and revised the manuscript. $\mathrm{MN}$ and AChe supervised the entire project. All authors contributed to the article and approved the submitted version.

\section{FUNDING}

The authors acknowledge financial support from the PhosAgro/UNESCO/IUPAC partnership in the ambit of the Green Chemistry for Life grant program (project no. 45003552865) and the Tunisian Ministry of Higher Education and Scientific Research in the ambit of the laboratory project LR11ES31.

\section{SUPPLEMENTARY MATERIAL}

The Supplementary Material for this article can be found online at: https://www.frontiersin.org/articles/10.3389/fbioe. 2020.00521/full\#supplementary-material 


\section{REFERENCES}

Ackerley, D. F., Barak, Y., Lynch, S. V., Curtin, J., and Matin, A. (2006). Effect of chromate stress on Escherichia coli K-12. J. Bacteriol. 188, 3371-3381. doi: 10.1128/JB.188.9.3371-3381.2006

Ackerley, D. F., Gonzalez, C. F., Keyhan, M., Blake, I. R., and Matin, A. (2004). Mechanism of chromate reduction by the Escherichia coli protein, NfsA, and the role of different chromate reductases in minimizing oxidative stress during chromate reduction. Environ. Microbiol. 6, 851-860. doi: 10.1111/j.1462-2920.2004.00639.x

Ahemad, M., and Kibret, M. (2014). Mechanisms and applications of plant growth promoting rhizobacteria: current perspective. J. King. Saud. Univ. Sci. 26, 1-20. doi: 10.1016/j.jksus.2013.05.001

Alexander, D. B., and Zuberer, D. A. (1991). Use of chrome azurol S reagents to evaluate siderophore production by rhizosphere bacteria. Biol. Fert. Soil. 12, 39-45. doi: 10.1007/BF00369386

Al-Kaisi, M. M., Elmore, R. W., Guzman, J. G., Hanna, H. M., Hart, C. E., Helmers, M. J., et al. (2013). Drought impact on crop production and the soil environment: 2012 experiences from Iowa. J. Soil. Water. Conserv. 68, 19-24. doi: $10.2489 /$ jswc.68.1.19A

Alvarez, A. H., Moreno-Sánchez, R., and Cervantes, C. (1999). Chromate efflux by means of the ChrA chromate resistance protein from Pseudomonas aeruginosa. J. Bacteriol. 181, 7398-7400. doi: 10.1128/JB.181.23.7398-7400.1999

Alves, A., Riesco, R., Correia, A., and Trujillo, M. E. (2015). Microbacterium proteolyticum sp. nov. isolated from roots of Halimione portulacoides. Int. J. Syst. Evol. Microbiol. 65, 1794-1798. doi: 10.1099/ijs.0.000177

Ashraf, S., Afzal, M., Naveed, M., Shahid, M., and Zahir, Z. A. (2018). Endophytic bacteria enhance remediation of tannery effluent in constructed wetlands vegetated with Leptochloa fusca. Int. J. Phytoremediat. 20, 121-128. doi: $10.1080 / 15226514.2017 .1337072$

Avramov, A. P., Couger, M. B., Hartley, E. L., Land, C., Wellendorf, R., Hanafy, R. A., et al. (2016). Draft genome sequence of Microbacterium oleivorans strain Wellendorf implicates heterotrophic versatility and bioremediation potential. Genom. Data. 10, 54-60. doi: 10.1016/j.gdata.2016.09.005

Aziz, R. K., Bartels, D., Best, A. A., DeJongh, M., Disz, T., Edwards, R. A., et al. (2008). The RAST server: rapid annotations using subsystems technology. BMC Genomics 9:75. doi: 10.1186/1471-2164-9-75

Baldiris, R., Acosta-Tapia, N., Montes, A., Hernández, J., and Vivas-Reyes, R. (2018). Reduction of hexavalent chromium and detection of Chromate Reductase (ChrR) in Stenotrophomonas maltophilia. Molecules 23:406. doi: 10.3390/molecules23020406

Balmer, J. (2018). Hexavalent chromium. Workplace Health Saf. 66:564. doi: $10.1177 / 2165079918805775$

Bankevich, A., Nurk, S., Antipov, D., Gurevich, A. A., Dvorkin, M., Kulikov, A. S., et al. (2012). SPAdes: a new genome assembly algorithm and its applications to single-cell sequencing. J. Comp. Biol.19, 455-477. doi: 10.1089/cmb.2012.0021

Bauer, A. W., Kirby, W. M., Sherris, J. C., and Turck, M. (1966). Antibiotic susceptibility testing by a standardized single disk method. Am. J. Clin. Pathol. $45,493-496$

Bharagava, R. N., and Mishra, S. (2018). Hexavalent chromium reduction potential of Cellulosimicrobium sp. isolated from common effluent treatment plant of tannery industries. Ecotox. Environ. Saf. 147, 102-109. doi: 10.1016/j.ecoenv.2017.08.040

Bhattacharyya, C., Bakshi, U., Mallick, I., Mukherji, S., Bera, B., and Ghosh, A. (2017). Genome-guided insights into the plant growth promotion capabilities of the physiologically versatile bacillus aryabhattai strain AB211. Front. Microbiol. 8:411. doi: 10.3389/fmicb.2017.00411

Bishnoi, U. (2015). "Chapter four - PGPR interaction: an ecofriendly approach promoting the sustainable agriculture system," in Advances Botanical Research, eds H. Bais and J. Sherrier (Newark, DE: Academic Press), 81-113.

Brown, S. D., Palumbo, A. V., Panikov, N., Ariyawansa, T., Klingeman, D. M., Johnson, C. M., et al. (2012). Draft genome sequence for Microbacterium laevaniformans strain OR221, a bacterium tolerant to metals, nitrate, and low pH. J. Bacteriol. 194, 3279-3280. doi: 10.1128/JB.00474-12

Cai, T., Ju, S., Lee, J., Sai, N., Demkov, A. A., Niu, Q., et al. (2009). Magnetoelectric coupling and electric control of magnetization in ferromagnet/ferroelectric/normal-metal superlattices. Phys. Rev. B. 80:140415. doi: 10.1103/PhysRevB.80.140415
Chai, L., Ding, C., Li, J., Yang, Z., and Shi, Y. (2019). Multi-omics response of Pannonibacter phragmitetus BB to hexavalent chromium. Environ. Pollut. 249, 63-73. doi: 10.1016/j.envpol.2019.03.005

Chen, H., Yin, Y., Feng, E., Li, Y., Xie, X., and Wang, Z. (2014). Thioredoxin peroxidase gene is involved in resistance to biocontrol fungus Nomuraea rileyi in Spodoptera litura: gene cloning, expression, localization and function. Dev. Comp. Immunol. 44, 76-85. doi: 10.1016/j.dci.2013.11.012

Collet, J. F., and Messens, J. (2010). Structure, function, and mechanism of thioredoxin proteins. Antioxid. Redox. Signal. 13, 1205-1216. doi: $10.1089 /$ ars. 2010.3114

Corretto, E., Antonielli, L., Sessitsch, A., Kidd, P., Weyens, N., and Brader, G. (2015). Draft genome sequences of 10 Microbacterium spp., with emphasis on heavy metal-contaminated environments. Genome. Announc. 3:e00432e00415. doi: 10.1128/genomeA.00432-15

Davis, I. W., Leaver-Fay, A., Chen, V. B., Block, J. N., Kapral, G. J., Wang, X., et al. (2007). MolProbity: all-atom contacts and structure validation for proteins and nucleic acids. Nucleic. Acids. Res. 35(Suppl. 2), W375-W383. doi: $10.1093 / \mathrm{nar} / \mathrm{gkm} 216$

Davis, S. R. (2005). An overview of the antifungal properties of allicin and its breakdown products - the possibility of a safe and effective antifungal prophylactic. Mycoses. 48, 95-100. doi: 10.1111/j.1439-0507.2004.01076.x

Dutta, J., and Thakur, D. (2017). Evaluation of multifarious plant growth promoting traits, antagonistic potential and phylogenetic affiliation of rhizobacteria associated with commercial tea plants grown in Darjeeling, India. PLOS ONE 12:e0182302. doi: 10.1371/journal.pone.0182302

Elahi, A., Ajaz, M., Rehman, A., Vuilleumier, S., Khan, Z., and Hussain, S. Z. (2019). Isolation, characterization, and multiple heavy metal-resistant and hexavalent chromium-reducing Microbacterium testaceum B-HS2 from tannery effluent. J. King. Saud. Univ. Sci. 31, 1437-1444. doi: 10.1016/j.jksus.2019.02.007

Fang, Z., Yong, Y. C., Zhang, J., Du, G., and Chen, J. (2017). Keratinolytic protease: a green biocatalyst for leather industry. Appl. Microbiol. Biotechnol. 101, 7771-7779. doi: 10.1007/s00253-017-8484-1

Fassy, J., Tsalkitzi, K., Salavagione, E., Hamouda-Tekaya, N., and Braud, V. M. (2017). A real-time digital bio-imaging system to quantify cellular cytotoxicity as an alternative to the standard chromium-51 release assay. Immunology. 150, 489-94. doi: 10.1111/imm.12702

Fu, J., Lv, H., and Chen. F. (2016). Diversity and Variation of Bacterial Community Revealed by MiSeq Sequencing in Chinese Dark Teas. PLoS One. 11:e0162719. doi: 10.1371/journal.pone.0162719

Gallois, N., Piette, L., Ortet, P., Bakarat, M., Long, J., Berthomieu, C., et al. (2018). Proteomics data for characterizing Microbacterium oleivorans A9, an uraniumtolerant actinobacterium isolated near the Chernobyl nuclear power plant. Data Brief 21, 1125-1129. doi: 10.1016/j.dib.2018.10.136

Galperin, M. Y., Makarova, K. S., Wolf, Y. I., and Koonin, E. V. (2015). Expanded microbial genome coverage and improved protein family annotation in the COG database. Nucleic Acids Res. 43, D261-D269. doi: 10.1093/nar/gk u1223

Gao, J. L., Sun, P., Wang, X. M., Lv, F. Y., and Sun, J. G. (2017). Microbacterium zeae sp. nov., an endophytic bacterium isolated from maize stem. Antonie Van Leeuwenhoek 110, 697-704. doi: 10.1007/s10482-017-0837-3

Grant, J. R., and Stothard, P. (2008). The CGView Server: a comparative genomics tool for circular genomes. Nucleic. Acids. Res. 36, W181-W84. doi: 10.1093/nar/gkn179

Gtari, M., Ghodhbane-Gtari, F., Nouioui, I., Beauchemin, N., and Tisa, L. S. (2011). Phylogenetic perspectives of nitrogen-fixing actinobacteria. Arch. Microbiol. 194, 3-11. doi: 10.1007/s00203-011-0733-6

Gupta, P., and Diwan, B. (2017). Bacterial Exopolysaccharide mediated heavy metal removal: a review on biosynthesis, mechanism and remediation strategies. Biotechnol. Rep. 13, 58-71. doi: 10.1016/j.btre.2016.12.006

Gutiérrez, J. C., Amaro, F., and Martín-González, A. (2015). Heavy metal wholecell biosensors using eukaryotic microorganisms: an updated critical review. Front. Microbiol. 6:48. doi: 10.3389/fmicb.2015.00048

Harish, R., Samuel, J., Mishra, R., Chandrasekaran, N., and Mukherjee, A. (2012). Bio-reduction of $\mathrm{Cr}$ (VI) by exopolysaccharides (EPS) from indigenous bacterial species of Sukinda chromite mine, India. Biodegradation 23, 487-496. doi: 10.1007/s10532-011-9527-4

Hassen, W., Neifar, M., Cherif, H., Najjari, A., Chouchane, H., Driouich, R. C., et al. (2018). Pseudomonas rhizophila S211, a new plant growth-promoting 
rhizobacterium with potential in pesticide-bioremediation. Front. Microbiol. 9:34. doi: 10.3389/fmicb.2018.00034

Henson, M. W., Santo Domingo, J. W., Kourtev, P. S., Jensen, R. V., Dunn, J. A., and Learman, D. R. (2015). Metabolic and genomic analysis elucidates strainlevel variation in Microbacterium spp. isolated from chromate contaminated sediment. PeerJ. 3:e1395. doi: 10.7717/peerj.1395

Humphries, A. C., Nott, K. P., Hall, L. D., and Macaskie, L. E. (2005). Reduction of $\mathrm{Cr}(\mathrm{VI})$ by immobilized cells of Desulfovibrio vulgaris NCIMB 8303 and Microbacterium sp. NCIMB 13776. Biotechnol. Bioeng. 90, 589-596. doi: 10.1002/bit.20450

Ibrahim, A. S. S., El-Tayeb, M. A., Elbadawi, Y. B., Al-Salamah, A. A., and Antranikian, G. (2012). Hexavalent chromate reduction by alkaliphilic Amphibacillus sp. KSUCr3 is mediated by copper-dependent membrane-associated $\mathrm{Cr}(\mathrm{VI})$ reductase. Extremophiles 16, 659-668. doi: 10.1007/s00792-012-0464-x

Jakov, B. (2005). "Costs of tannery waste treatment," in 15th Session of the UNIDO Leather and Leather Products Industry Panel (Leon).

Jana, G. A., Al-Yahyai, R., and Yaish, M. W. (2017). Genome sequencing of Microbacterium sp. Yaish 1, a bacterial strain isolated from the rhizosphere of date palm trees affected by salinity. Genome Announc. 5:e01247-17 doi: 10.1128/genomeA.01247-17

Jensen, H. L. (1942). Nitrogen fixation in leguminous plants. I. General characters of root-nodule bacteria isolated from species of Medicago and Trifolium in Australia. P. Linn. Soc. N. S. W. 67, 98-108.

John, S. G., Ruggiero, C. E., Hersman, L. E., Tung, C. S., and Neu, M. P. (2001). Siderophore mediated plutonium accumulation by Microbacterium flavescens (JG-9). Environ. Sci. Technol. 35, 2942-2948. doi: 10.1021/es010590g

Johnstone, T. C., and Nolan, E. M. (2015). Beyond iron: Non-classical biological functions of bacterial siderophores. Dalton Trans. 44, 6320-6339. doi: $10.1039 / \mathrm{C} 4 \mathrm{DT} 03559 \mathrm{C}$

Kang, S. M., Radhakrishnan, R., Khan, A. L., Kim, M. J., Park, J. M., Kim, B. R., et al. (2014). Gibberellin secreting rhizobacterium, Pseudomonas putida $\mathrm{H}-2-$ 3 modulates the hormonal and stress physiology of soybean to improve the plant growth under saline and drought conditions. Plant. Physiol. Biochem. 84, 115-124. doi: 10.1016/j.plaphy.2014.09.001

Khanna, K., Jamwal, V. L., Sharma, A., Gandhi, S. G., Ohri, P., Bhardwaj, R., et al. (2019). Supplementation with plant growth promoting rhizobacteria (PGPR) alleviates Cadmium toxicity in Solanum lycopersicum by modulating the expression of secondary metabolites. Chemosphere 230, 628-639. doi: 10.1016/j.chemosphere.2019.05.072

Kim, M., Oh, H. S., Park, S. C., and Chun, J. (2014). Towards a taxonomic coherence between average nucleotide identity and 16S rRNA gene sequence similarity for species demarcation of prokaryotes. Int. J. Syst. Evol. Microbiol. 64, 346-351. doi: 10.1099/ijs.0.059774-0

Kim, O., Cho, Y., Lee, K., Yoon, S., Kim, M., Na, H., et al. (2012). Introducing EzTaxon-e: a prokaryotic 16S rRNA gene sequence database with phylotypes that represent uncultured species. Int. J. Syst. Evol. Microbiol. 62, 716-721. doi: 10.1099/ijs.0.038075-0

Kumar, M., and Saini, H. S. (2019). Reduction of hexavalent chromium (VI) by indigenous alkaliphilic and halotolerant Microbacterium sp. M5: comparative studies under growth and nongrowth conditions. J. Appl. Microbiol. 127, 1057-1068. doi: 10.1111/jam.14366

Kumar, S., Stecher, G., and Tamura, K. (2016). MEGA7: molecular evolutionary genetics analysis version 7.0 for bigger datasets. Mol. Biol. Evol. 33, 1870-1874. doi: $10.1093 / \mathrm{molbev} / \mathrm{msw} 054$

Learman, D. R., Ahmad, Z., Brookshier, A., Henson, M. W., Hewitt, V., Lis, A., et al. (2019). Comparative genomics of 16 Microbacterium spp. that tolerate multiple heavy metals and antibiotics. PeerJ. 6:e6258. doi: 10.7717/peerj.6258

Learman, D. R., Voelker, B. M., Vazquez-Rodriguez, A. I., and Hansel, C. M. (2011). Formation of manganese oxides by bacterially generated superoxide. Nat. Geosci. 4, 95-98. doi: 10.1038/ngeo1055

Li, H., Li, Z., Liu, T., Xiao, X., Peng, Z., and Deng, L. (2008). A novel technology for biosorption and recovery hexavalent chromium in wastewater by bio-functional magnetic beads. Bioresour. Technol. 99, 6271-6279. doi: 10.1016/j.biortech.2007.12.002

Li, X., and Krumholz, L. R. (2009). Thioredoxin is involved in U(VI) and Cr(VI) reduction in Desulfovibrio desulfuricans G20. J. Bacteriol. 191, 4924-4933. doi: 10.1128/JB.00197-09
Li, Y., and Ma, Q. (2017). Iron acquisition strategies of vibrio anguillarum. Front. Cell. Infect. Microbiol. 7:342. doi: 10.3389/fcimb.2017.00342

Lun, L., Li, D., Yin, Y., Li, D., Xu, G., Zhao, Z., et al. (2016). Characterization of chromium waste form based on biocementation by Microbacterium sp. GM-1. Indian. J. Microbiol. 56, 353-60. doi: 10.1007/s12088-016-0579-3

Mahjoubi, M., Aliyu, H., Cappello, S., Neifar, M., Souissi, Y., Cowan, D. A., et al. (2019). The genome of Alcaligenes aquatilis strain BU33N: insights into hydrocarbon degradation capacity. PLoS ONE 14:e0221574. doi: 10.1371/journal.pone.0221574

Manzanera, M., García-Fontana, C., Vílchez, J. I., Narváez-Reinaldo, J. J., and González-López, J. (2015). Genome sequence of Microbacterium sp. strain 3J1, a highly desiccation tolerant bacterium that promotes plant growth. Genome Announc. 3:e00713-15. doi: 10.1128/genomeA.00713-15

Maqbool, Z., Asghar, H. N., Shahzad, T., Hussain, S., Riaz, M., Ali, S., et al. (2015). Isolating, screening and applying chromium reducing bacteria to promote growth and yield of okra (Hibiscus esculentus L.) in chromium contaminated soils. Ecotox. Environ. Saf. 114, 343-349. doi: 10.1016/j.ecoenv.2014.07.007

Markowitz, V. M., Mavromatis, K., Ivanova, N. N., Chen, I.-M. A., Chu, K., and Kyrpides, N. C. (2009). IMG ER: a system for microbial genome annotation expert review and curation. Bioinformatics 25, 2271-2278. doi: 10.1093/bioinformatics/btp393

McCord, J. M., and Fridovich, I. (1988). Superoxide dismutase: The first twenty years (1968-1988). Free. Radic. Biol. Med. 5, 363-369. doi: 10.1016/0891-5849(88)90109-8

McNicholas, S., Potterton, E., Wilson, K. S., and Noble, M. E. M. (2011). Presenting your structures: the CCP4mg molecular-graphics software. Acta Crystallogr. D Biol. Crystallogr. 67, 386-394. doi: 10.1107/S0907444911007281

Morohoshi, T., Wang, W. Z., Someya, N., and Ikeda, T. (2011). Genome sequence of Microbacterium testaceum StLB037, an N-acylhomoserine lactonedegrading bacterium isolated from potato leaves. J. Bacteriol. 193, 2072-2073. doi: 10.1128/JB.00180-11

Naseem, H., Ahsan, M., Shahid, M. A., and Khan, N. (2018). Exopolysaccharides producing rhizobacteria and their role in plant growth and drought tolerance. J. Basic. Microbiol. 58, 1009-1022. doi: 10.1002/jobm.201800309

Neifar, M., Chouchane, H., Najjari, A., El Hidri, D., Mahjoubi, M., Ghedira, K., et al. (2019). Genome analysis provides insights into crude oil degradation and biosurfactant production by extremely halotolerant Halomonas desertis G11 isolated from Chott El-Djerid salt-lake in Tunisian desert. Genomics 111, 1802-1814. doi: 10.1016/j.ygeno.2018.12.003

Ogata, H., Goto, S., Sato, K., Fujibuchi, W., Bono, H., and Kanehisa, M. (1999). KEGG: kyoto encyclopedia of genes and genomes. Nucleic. Acids. Res. 27, 29-34. doi: 10.1093/nar/27.1.29

Ouertani, A., Chaabouni, I., Mosbah, A., Long, J., Barakat, M., Mansuelle, P., et al (2018). Two new secreted proteases generate a casein-derived antimicrobial peptide in Bacillus cereus food born isolate leading to bacterial competition in milk. Front. Microbiol. 9:1148. doi: 10.3389/fmicb.2018.01148

Passari, A. K., Rajput, V., Zothanpuia, P.riya, L. P. M., Dharne, M., Dastager, S., Mathew, O. K., et al. (2019b). Draft genome sequence of plant growthpromoting endophytic Microbacterium hydrothermale BPSAC84, isolated from the medicinal plant Mirabilis jalapa. Microbiol. Resour. Announc. 8, e00406e00419. doi: 10.1128/MRA.00406-19

Passari, A. K., Upadhyaya, K., Singh, G., AbdelAzeem, A. M., Thankappan, S., Uthandi, S., et al. (2019a). Enhancement of disease resistance, growth potential, and photosynthesis in tomato (Solanum lycopersicum) by inoculation with an endophytic actinobacterium, Streptomyces thermocarboxydus strain BPSAC147. PLoS ONE 14:e219014. doi: 10.1371/journal.pone. 0219014

Pattanapipitpaisal, P., Brown, N., and Macaskie, L. (2001). Chromate reduction and 16S rRNA identification of bacteria isolated from a $\mathrm{Cr}(\mathrm{VI})$-contaminated site. Appl. Microbiol. Biotechnol. 57, 257-261. doi: 10.1007/s002530100758

Payne, S. M., Mey, A. R., and Wyckoff, E. E. (2016). Vibrio iron transport: evolutionary adaptation to life in multiple environments. Microbiol. Mol. Biol. Rev. 80, 69-90. doi: 10.1128/MMBR.00046-15

Penrose, D. M., and Glick, B. R. (2003). Methods for isolating and characterizing ACC deaminase-containing plant growth-promoting rhizobacteria. Physiol. Plant. 118, 10-15. doi: 10.1034/j.1399-3054.2003.00086.x

Pikovskaya, R. I. (1948). Mobilization of phosphorus in soil in connection with the vital activity of some microbial species. Microbiology. 17, 362-370. 
Pradhan, S. K., Singh, N. R., Rath, B. P., and Thatoi, H. (2016). Bacterial chromate reduction: a review of important genomic, proteomic, and bioinformatic analysis. Crit. Rev. Env Sci. Tec. 46, 1659-1703. doi: 10.1080/10643389.2016.1258912

Ramirez-Diaz, M. I., Diaz-Perez, C., Vargas, E., Riveros-Rosas, H., Campos-Garcia, J., and Cervantes,. C. (2008). Mechanisms of bacterial resistance to chromium compounds. Biometals 21, 321-332. doi: 10.1007/s10534-007-9121-8

Reardon, T., Timmer, C. P., and Berdegue, J. A. (2004). The rapid rise of supermarkets in developing countries: induced organizational, institutional, and technological change in agrifood systems. eJADE 1, 168-183. doi: 10.22004/ag.econ.12005

Richter, M., and Rosselló-Móra, R. (2009). Shifting the genomic gold standard for the prokaryotic species definition. Proc. Natl. Acad. Sci. U.S.A. 106, 19126-19131. doi: 10.1073/pnas.0906412106

Richter, M., Rosselló-Móra, R., Oliver-Glöckner, F., and Peplies, J. (2016). JSpeciesWS: a web server for prokaryotic species circumscription based on pairwise genome comparison. Bioinformatics 32, 929-931. doi: 10.1093/bioinformatics/btv681

Sau, G. B., Chatterjee, S., and Mukherjee, S. K. (2010). Chromate reduction by cell-free extract of Bacillus firmus KUCr1. Pol. J. Microbiol. 59, 185-190. doi: $10.33073 / \mathrm{pjm}-2010-029$

Schippers, A., Neretin, L. N., Kallmeyer, J., Ferdelman, T. G., Cragg, B. A., Parkes, R. J., et al. (2005). Prokaryotic cells of the deep sub-seafloor biosphere identified as living bacteria. Nature 433, 861-864. doi: 10.1038/nature03302

Soni, S. K., Singh, R., Awasthi, A., and Kalra, A. (2014). A Cr(VI)-reducing Microbacterium sp. strain SUCR140 enhances growth and yield of Zea mays in $\mathrm{Cr}(\mathrm{VI})$ amended soil through reduced chromium toxicity and improves colonization of arbuscular mycorrhizal fungi. Environ. Sci. Pollut. R. 21, 1971-1979. doi: 10.1007/s11356-013-2098-7

Souii, A., Guesmi, A., Ouertani, R., Cherif, H., Chouchane, H., Cherif, A., et al. (2018). Carboxymethyl cellulase production by extremotolerant bacteria in low-cost media and application in enzymatic saccharification of stevia biomass. Waste. Biomass. Valori. 11, 2111-2122. doi: 10.1007/s12649-018-0496-2

Spaepen, S., and Vanderleyden, J. (2011). Auxin and plant-microbe interactions. Cold. Spring. Harb. Perspect. Biol. 3:a001438. doi: 10.1101/cshperspect.a001438
Suthanthararajan, R., Ravindranath, E., Chits, K., Umamaheswari, B., Ramesh, T., and Rajamam, S. (2004). Membrane application for recovery and reuse of water from treated tannery wastewater. Desalination 164, 151-156. doi: 10.1016/S0011-9164(04)00174-2

Thanikaivelan, P., Rao, J. R., Nair, B. U., and Ramasami, T. (2004). Progress and recent trends in biotechnological methods for leather processing. Trends. Biotechnol. 22, 181-188. doi: 10.1016/j.tibtech.2004.02.008

Wu, Y. H., Zhou, P., Cheng, H., Wang, C. S., Wu, M., and Xu, X. W. (2015). Draft genome sequence of Microbacterium profundi Shh49T, an actinobacterium isolated from deep-sea sediment of a polymetallic nodule environment. Genome. Announc. 3:e00642-15. doi: 10.1128/genomeA.00642-15

Yang, J., Roy, A., and Zhang, Y. (2013). Protein-ligand binding site recognition using complementary binding-specific substructure comparison and sequence profile alignment. Bioinformatics 29, 2588-2595. doi: 10.1093/bioinformatics/btt447

Yang, J., and Zhang, Y. (2015). I-TASSER server: new development for protein structure and function predictions. Nucleic. Acids. Res. 43, W174-W181. doi: 10.1093/nar/gkv342

Zeng, J., Gou, M., Tang, Y. Q., Li, G.Y., Sun, Z.Y., and Kida, K. (2016). Effective bioleaching of chromium in tannery sludge with an enriched sulfur-oxidizing bacterial community. Bioresour. Technol. 218, 859-866. doi: 10.1016/j.biortech.2016.07.051

Conflict of Interest: The authors declare that the research was conducted in the absence of any commercial or financial relationships that could be construed as a potential conflict of interest.

Copyright (c) 2020 Ouertani, Ouertani, Mahjoubi, Bousselmi, Najjari, Cherif, Chamkhi, Mosbah, Khdhira, Sghaier, Chouchane, Cherif and Neifar. This is an open-access article distributed under the terms of the Creative Commons Attribution License (CC BY). The use, distribution or reproduction in other forums is permitted, provided the original author(s) and the copyright owner(s) are credited and that the original publication in this journal is cited, in accordance with accepted academic practice. No use, distribution or reproduction is permitted which does not comply with these terms. 